\title{
Adaptation of the Student Expectations of Online Learning Survey Revised (SEOLS-R) into Turkish "
}

\author{
Ömer Arslan ${ }^{\mathrm{a}}$, Gökhan Dağhan ${ }^{\mathrm{b}}$ and Buket Akkoyunlu ${ }^{\mathrm{c}}$

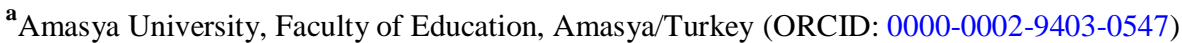 \\ ${ }^{\mathbf{b}}$ Hacettepe University, Faculty of Education, Ankara/Turkey (ORCID: 0000-0002-3182-2862) \\ ${ }^{\mathbf{c}}$ Çankaya University, Department of Inter-Curricular Courses, Ankara/Turkey (ORCID: 0000-0003-1989-0552)
}

Article History: Received: 1 December 2019; Accepted: 8 July 2020; Published online: 13 August 2020

\begin{abstract}
The aim of this study is to adapt the Student Expectations of Online Learning Survey Revised [SEOLS-R] developed by Harris, Larrier and Castano-Bishop (2011) into Turkish. For this purpose, the adaptation process of the scale, which consists of 7 factors and 43 items in the 5-point Likert structure, started first with the necessary permissions, and then a translation and cultural adaptation process was carried out. After the cultural adaptation process, the construct validity of the scale was tested with 411 students who study in distance education programs of Amasya University. After the construct validity findings, the reliability values of the scale were examined. In line with the findings, it was concluded that the Turkish version of the SEOLS-R scale is a valid and reliable measurement tool suitable for Turkish culture.
\end{abstract}

Keywords: Online learning, student expectations, validity and reliability, scale adaptation

DOI:10.16949/turkbilmat.653684

Öz: Bu çalışmanın amacı Harris, Larrier ve Castano-Bishop (2011) tarafından geliştirilen Revize Edilmiş Çevrimiçi Öğrenmeye İlişkin Öğrenci Beklentileri Ölçeği'ni (Student Expectations of Online Learning Survey Revised [SEOLS-R]) Türkçeye uyarlamaktır. Bu amaçla özgün formu 5'li Likert yapıda 7 faktör ve 43 maddeden oluşan ölçeğin uyarlanması süreci, ilk olarak gereken izinlerin alınmasıyla başlamış, daha sonra çeviri ve kültürel adaptasyon süreci gerçekleştirilmiştir. Kültürel adaptasyon sürecinin ardından Amasya Üniversitesi'nin uzaktan eğitim programlarına devam etmekte olan 411 öğrenci üzerinde ölçeğin yapı geçerliği sınanmıştır. Yapı geçerliği bulgularının ardından ölçeğin güvenirlik değerleri incelenmiştir. Elde edilen bulgular doğrultusunda, SEOLS-R ölçeğinin Türkçe formunun, Türk kültürüne uygun, geçerli ve güvenilir bir ölçme aracı olabileceği sonucuna ulaşılmıştır.

Anahtar Kelimeler: Çevrimiçi öğrenme, öğrenci beklentileri, geçerlik ve güvenirlik, ölçek uyarlama

Türkçe sürüm için tıklayınız

\section{Introduction}

Many factors in adult students' daily livings, such as family responsibilities, time constraints and overtime dependencies, lead to the preference of online distance education programs rather than formal education. At this point, online distance education programs can offer very favorable opportunities to enable such students to study. Students who enroll in these programs and begin their education, and who have successfully fulfilled the requirements of the program, can obtain a better future, a better working position, more professional knowledge or higher academic degrees. However, for these programs, success is not always possible for students who spend time, money and effort as well as their responsibilities. Dropping out the programs due to unmet expectations, responsibilities or failure to fulfill the requirements of the program can turn into serious losses both in terms of the individual's future planning and the academic units such as Distance Education Application and Research Centers. According to Okur, Paşaoğlu-Baş and Uça-Güneş (2019), it is one of the reasons for students who do not have an academic or professional career expectation to give up more easily in the face of adverse events they encounter, and to leave school or not enroll. Harris, Larrier and Castano-Bishop (2011) emphasize that the problem of student loss in online learning environments of higher education institutions has attracted the attention of distance education administrators. In order to prevent these losses, examining the expectations of students regarding online learning environments may enable them to better understand the dropout action and to produce solutions. According to Okur et al. (2019), determining the reasons for dropping out of education can provide important data on the solution of drop out problems. In this way, it is possible to make an inference whether students' expectations from the programs are realistic, and to what extent the methods, techniques or materials used by the instructors meet the requirements of the students and programs. Examining and well determining the interactions between students, their communication with their instructors and the support they

Corresponding Author: Gökhan Dağhan (D) email: gokhand@hacettepe.edu.tr

* This research is based upon the first author's master's thesis under the supervision of the second author.

Citation Information: Arslan, Ö., Dağhan, G., \& Akkoyunlu, B. (2020). Adaptation of the student expectations of online learning survey revised (SEOLS-R) into Turkish. Turkish Journal of Computer and Mathematics Education, 11(2), 438-460. 
need during the education process from the registration to graduate can help to prevent students from dropping out.

The main concern of educators is the increase in the number of students who do not continue their education even though they have started their education in the process which educators focused on designing, developing and providing appropriate online learning environments (O’Brien, 2002; Parker, 1999). Generally, distance education dropout rates are higher than face-to-face education dropout rates. Many students drop out online classes or try to finish them unsatisfactorily (Keegan, 1990; Morgan \& Tam, 1999; Willging \& Johnson, 2009). According to Rovai (2003), the completion rate of the education process can be used as a measure of the quality of education. While the rate of dropping out campus education is between $15 \%$ and $25 \%$, it can be up to $40 \%$ in online courses (Parker, 1999, 2003; Xenos, 2004). The low completion rate of open education and online distance education programs may be due to student-related reasons such as learner characteristics, motivation, and satisfaction (Willging \& Johnson, 2009), and students' job and family responsibilities (Xenos, Pierrakeas, \& Pintelas, 2002) can prevent them from continuing education.

There are limited number of studies, which handle students' dropout rates of distance education programs in Turkey. In these studies, it is seen that the dropout causes are generally studied, but the dropout rates are not mentioned. In their review study, Okur et al. (2019) stated that dropout factors are about the school and the program, personal characteristics of the students, and the social environment. Arslan (2018) classified educational dropout under the headings of internal factors, external factors, preference reasons, personal characteristics and expectations. However, numeric data are unknown related to dropout rates in Turkey. First, there is a need for inclusive quantitative data about rates and statistics. Then, it is necessary to examine the persistence / dropout rates and their causes comparatively.

It is emphasized in the literature that one of the important factors in dropping out online distance education programs is the inability of students to meet their expectations (Bezerra \& Silva, 2017; Laskaris, 2015; Onah, Sinclair, \& Boyatt, 2014). Arslan (2018) has stated that one of the factors causing dropout in Turkish literature is expectations. At this point, Harris et al. (2011) state that the theoretical framework of the SEOLS-R scale is based on the Expectation Theory. This theory provides a framework that explains how to confirm to what extent the expected results of future actions are met (Isaac, Zerbe, \& Pitt, 2001). In the context of continuing online education and not to dropout courses, Expectation Theory corresponds to the extent to which students' expectations in online courses are met will affect whether students will continue to take online courses. When student expectations are consistent with lesson experiences, students are more likely to spend time in an online learning environment. Having knowledge and understanding of student expectations and how these expectations affect student performance and retention is the first step in developing programs that will help students develop realistic expectations for online courses.

In this study, Expectation Theory, which is the theoretical basis of the SEOLS-R scale, is based on the study of Vroom (1964). Later, Porter and Lowler (1968) developed a model on effort-performance relationship. Although this model is often called the Expectation Theory, it is also known as the VIE theory and is explained in a sequence of V (valence), I (instrumentality) and E (expectancy) (Isaac, Zerbe, \& Pitt, 2001). According to Vroom (1964), valance is a mental animation-focused value that helps an individual to choose between various results (Anik, 2007). Instrumentality is a concept that is more suitable for situations where there are intermediate objectives and focuses on other intermediate objectives in order to achieve an award. According to An1k (2007), instrumentality shows that one's behavior can be explained by shaping his belief that he can achieve a result that he believes will be satisfied by a certain set of tools. The concept of expectancy, which is the last basic component of the Expectation Theory, is the inner prediction, belief or opinion developed by an individual in order to achieve a goal. Expectation Theory is actually a theory of motivation and behavior. The relationship between the SEOLS-R scale and Expectation Theory discussed in this study comes from the assumption that students are more likely to continue and graduate in online programs if their expectations for online education are met (Harris et al., 2011). Therefore, the SEOLS-R scale is a reliable measurement tool measures the structures that may affect students' continuance to online classes quantitatively (Harris et al., 2011).

Emphasizing that many studies address the reasons for dropping out online distance education programs, but few studies have examined the relationship between student expectations and dropouts. Harris et al. (2011) pointed out that a systematic method is needed to fill this gap in the literature. At this point, the SEOLS-R scale was developed by Harris et al. (2011) in order to determine the expectations of students dropping out online distance education programs. No other scale has been developed in the literature for this purpose. Although many scales have been developed or adapted in the literature on topics such as learner readiness, community feeling, student engagement, motivation, and attitude towards online learning, they will be able to explain the reasons for dropping out online distance learning programs pointed out by Harris et al. (2011). The lack of a student expectations scale is an important deficiency. Therefore, the purpose of this research is to adapt the SEOLS-R scale to Turkish. Since the validity and reliability study of SEOLS-R has not been carried out in Turkish culture before, the cultural adaptation studies of the scale were made in the context of this study, and 
then its validity and reliability were examined. Adapting such a scale to the Turkish culture is considered important in terms of having the potential to measure student expectations in online distance education, which is becoming more and more widespread at national level, and to have the opportunity to take some measures at the point of dropping out after these expectations are determined.

\section{Method}

This research is an intercultural scale adaptation study. For this purpose, it was aimed to adapt the scale into Turkish which is originally developed in English. In this adaptation process, the suitable scale adaptation steps of Deniz (2007) were followed without changing the order for this study. These steps are explained under this title.

\subsection{Participants}

In the adaptation process of the SEOLS-R scale, data were collected from 411 students who were attending to distance education programs of Amasya University. These students enrolled in the Pedagogical Formation Education Certificate Program and they take all theoretical lessons entirely through online learning. Students answered the SEOLS-R scale and a short questionnaire consisting of demographic information online. The students were informed about the fact that their answers will remain confidential, the data will not be used for any purposes other than this research, and all students are voluntarily participated in the research. 148 (36\%) of the students participating in the study are male and $263(64 \%)$ are female. The age distribution of the participants varies between 21 and 42, and the average age is 26.06 (standard deviation: 4.11). In terms of marital status, $76 \%(\mathrm{n}=313)$ of the participants are single and $24 \%(\mathrm{n}=98)$ are married. While $14 \%(\mathrm{n}=59)$ of the participants have previously attended in an online education program, $86 \%(\mathrm{n}=352)$ have not attended in any online education program.

\subsection{Information about the Original Scale}

The theoretical foundations of the SEOLS-R scale are based on the Expectation Theory. Harris et al. (2011) emphasized that expectations are the basic principles of human behavior and the degree of meeting individual expectations in various situations effect their latter behavior preferences. According to this view, they state that the extent to which a student's expectations are met in the online course will affect whether the student continues to take the online course. Based on this assumption, the researchers decided that there is a need for an instrument that can measure students' online learning expectations. The initial version of this instrument has 44 items and its validity and reliability studies were carried out. For validity study, face validity and content validity were examined. Item-total correlations and Cronbach alpha internal consistency coefficients were calculated for reliability. Two panels consisting of students and experts examined the scale and expressed their views for face validity. For content validity, the opinions of the panel consisting of experts were used as a base. For reliability, Cronbach alpha internal consistency coefficients of each dimension ranged from .64 to .95. Items with total item correlations of 0.25 or higher were kept in the questionnaire. After this first pilot study, some items were added and deleted, thus the scale was revised and reached its final shape consisting of 7 factors and 43 items in a 5point Likert structure.

The aim of the SEOLS-R scale developed by Harris et al. (2011) is to measure students' online learning expectations in terms of proficiency with technology, expectations of the online instructor, expectations about course content, expectations about social interaction, expectations about course navigation, facilitators associated with successful online learning, and proficiency with the course delivery system. The proficiency with technology dimension aims to determine the level of individual's basic skills related to computer usage. An example item from this dimension is "I am proficient in using a computer on my own". The dimension of expectations for the online instructor aims to determine the expectations of participants from online instructor during the teaching process. An example item from this dimension is "I expect the course instructor to be clear in communicating the goals of the course". Expectations about course content dimension aims to measure students' expectations about how an online course should be taught. An example from this dimension is "I expect this online course to provide me with opportunities for active learning". Expectations about social interaction dimension includes participants' expectations regarding how social relationships should be in online learning environment. An example item from this dimension is "I expect that online interactions with my classmates will be as frequent as face to face interactions". Expectations about course navigation dimension aims to measure expectations of participants about accessing easily to instructions and materials of the course, making course topic titles and forum names clear and more comprehensible. An example item from this dimension is "I expect the course materials to be easy to locate". The dimension of facilitators associated with successful online learning aims to determine the level of role of family, friends, positive factors related to online courses and personal factors that facilitate the success of participants in online learning process. An example item from this dimension is "I feel that having the support of my friends will enable me to succeed in this course". Finally, the proficiency with the course delivery system dimension aims to measure the perceptions of participants about how well they are able to use the features of online learning environments such as sending text messages, uploading 
assignments and using discussion forums. An example item for this dimension is "I am proficient in using the Dropbox feature in the courseroom". SEOLS-R is an instrument consisting of 7 sub-dimensions as mentioned above. Participants indicate their approval levels to the statements in each sub-dimension by marking one of the options extending from Strongly Disagree (1) to Strongly Agree (5). High scores from each sub-dimension means that the participants' evaluations regarding the related sub-dimension are positive or their expectations are high. A minimum score of 43 and a maximum of 215 can be obtained from the scale.

\subsection{Preparation of the Turkish Form of the Scale}

In order to adapt the SEOLS-R, the owners of the scale were first contacted via e-mail and the necessary permission was obtained to adapt the scale. In the second stage, the translation process of the scale was carried out. Steps suggested by Brislin (1970) were followed in the translation process of the scale. The original scale was translated into Turkish by researchers at first. Subsequently, a back-translation process was carried out by another researcher working in the Department of Computer Education and Instructional Technologies and who has knowledge of the Turkish and English languages, also has knowledge about scale development and adaptation studies. This researcher has the experience of teaching online in distance education, and also has a manager role in Distance Education Application and Research Center. In the third stage, the draft scale that was translated back was compared with the original scale, and a limited number of items that could not be reconciled was re-translated. Then, another researcher who is not familiar with the research subject but fluent in the English language translated back the items in the scale and compared with the original ones. At the end of this process, it was seen that the items with reverse translation process and the items in the original scale were the same. At this point, it has been seen that there is no semantic or conceptual equivalence lack between languages in the sense of terms or concepts. Following the linguistic adaptation of SEOLS-R to the Turkish language, the validity and reliability of the scale were examined.

\subsection{Data analysis}

Confirmatory factor analysis was performed to examine the construct validity of SEOLS-R. Two types of factor analysis are frequently used in the literature to test the construct validity of the scales (Brown, 2015; Harrington, 2009). These are exploratory factor analysis and confirmatory factor analysis. Exploratory factor analysis is a multivariate statistical method used by researchers to determine the factor structure of the scales in which they previously had little or no knowledge of the factor structure, in other words, to develop a theoretical structure, whereas confirmatory factor analysis is a multivariate statistical method used to test whether an existing theoretical structure is similar in a different sample or culture (Brown, 2015). The factor structure of the scale is not known in exploratory factor analysis. In confirmatory factor analysis, it is aimed to determine whether a known factor structure is similar in a different culture or sample. Similarly, in this study, confirmatory factor analysis was used to determine whether the factor structure determined by SEOLS-R by Harris et al. (2011) is similar in Turkish culture.

In this study, Mplus (Muthén \& Muthén, 2011) program was used in conducting confirmatory factor analysis. The responses of the participants to the SEOLS-R items were analyzed using the Weighted Least Squares Means and Variance Adjusted (WLSMV). The researchers state that the maximum likelihood estimation method, which is frequently used in confirmatory factor analysis, can produce inaccurate results when used with sorting scale items that do not show normal distribution or have a limited number of response categories (Finney \& DiStefano, 2006). In the literature, it is stated that WLSMV prediction method offers more accurate factor loading value estimates, more accurate goodness-of-fit indices in Likert type scales with a limited number of answering categories, and also perform better in samples which are small and does not show normal distribution (Beauducel \& Herzberg, 2006). In this context, WLSMV estimation method was used in this study, considering that SEOLS-R items consist of Likert type scale items with a limited number of answering categories. In the confirmatory factor analysis, the model-data fit of the model tested is examined through the goodness of fit indexes. The Mplus program creates four different goodness of fit indices that are recommended to be reported when using the WLSMV prediction method (McDonald \& Ho, 2002). These are the normed chi-square (NC) $\left(\chi^{2} / \mathrm{df}\right)$, The Root Mean Square Error of Approximation (RMSEA), Comparative Fit Index (CFI), Non Normed Fit Index [NNFI] or Tucker-Lewis Index [TLI]). TLI is also known as NNFI in the literature (Cangur \& Ercan, 2015). Little (2013) states that TLI index is reported in Mplus software and NNFI is reported in LISREL software, although both are developed by different research groups at different times, the preference belongs to the authors during their use in researches.

As a general rule to evaluate model-data fit in the literature, $\chi^{2} / \mathrm{df}$ value is greater than 2 and less than or equal to $5\left(2<\chi^{2} / \mathrm{df} \leq 5\right)$, RMSEA value is between .05 and $.08(0.05 \leq \mathrm{RMSEA} \leq 0.08)$ indicates acceptable fit. On the other hand, acceptable fit values for CFI and TLI values are .90 and above (Hu \& Bentler, 1999; Kline, 2011; Marsh, Balla, \& McDonald, 1988; McDonald \& Marsh, 1990). Perfect fit values for the above indices are below 2 for $\chi^{2} / \mathrm{df}$ ratio, .95 and above for CFI and TLI, .05 and below for RMSEA (Hu \& Bentler, 1999; Kline, 2011; Marsh et al., 1988; McDonald \& Marsh, 1990). 
Before analyzing the data by confirmatory factor analysis, the collected data were examined. Whether data extraction is required is considered. Since the data were collected online, all questions were answered. Therefore, there is no missing data. Since there is no outlier in the data set, no data extraction was made. The collected data set is included in the analysis as it is.

Before the factor analysis, Kaiser-Meyer-Olkin (KMO) Sampling Adequacy Test and Bartlett's Sphericity Test were carried out to test the adequacy of the sampling for analysis. It was found that KMO value is .856 and $\chi^{2}=8877.664 ; \mathrm{p}<.05$. These statistics indicate that the data can be factored, and the sample size is adequate.

The reliability of SEOLS-R was analyzed through item total correlations, Cronbach Alpha internal consistency coefficients and composite reliability coefficients.

\section{Findings}

In this section, firstly, the construct validity findings of the Turkish form of the SEOLS-R scale, and then the reliability findings are presented.

\subsection{Validity Findings}

Confirmatory factor analysis was performed to determine whether the seven-factor structure of SEOLS-R proposed by Harris et al. (2011) is also valid for Turkish culture. Before conducting confirmatory factor analysis, factor variances of each item were fixed to 1 and factors were allowed to be related in order to identify the model. The reason for this is to provide an opportunity to be scaled for each structure in the scale and prevent scale uncertainty. According to Brown (2015), fixing factor variances to 1 defines the model and parameter estimates allow to reproduce the input matrix perfectly. As a result of the confirmatory factor analysis performed, the data fit of the tested model was found to be acceptable [ $\chi^{2}(839): 1865.877, \chi^{2} / \mathrm{df}: 2.224$, CFI: .938, TLI: .934, RMSEA: .055, RMSEA 90\% Confidence Interval Lower Limit: .051, RMSEA 90\% Confidence Interval Upper Limit: .058]. These fit values are one-time fit values without any modification.

Table 1. Results of confirmatory factor analysis

\begin{tabular}{|c|c|c|c|c|}
\hline & $\lambda$ & S.E. & $\mathbf{Z}$ & $\mathbf{R}^{2}$ \\
\hline \multicolumn{5}{|c|}{ PT (Factor 1) } \\
\hline I1 & .779 & .036 & 21.940 & .607 \\
\hline $\mathrm{I} 2$ & .768 & .033 & 23.258 & .591 \\
\hline $\mathrm{I} 3$ & .908 & .026 & 34.378 & .825 \\
\hline I4 & .894 & .020 & 44.473 & .800 \\
\hline I5 & .883 & .030 & 29.826 & .780 \\
\hline I6 & .943 & .018 & 52.576 & .890 \\
\hline $\mathrm{I} 7$ & .898 & .026 & 33.961 & .806 \\
\hline \multicolumn{5}{|c|}{ EOI (Factor 2) } \\
\hline I8 & .673 & .047 & 14.312 & .453 \\
\hline I9 & .783 & .044 & 17.784 & .613 \\
\hline $\mathrm{I} 10$ & .740 & .040 & 18.362 & .548 \\
\hline I11 & .774 & .045 & 17.272 & .599 \\
\hline $\mathrm{I} 12$ & .718 & .041 & 17.400 & .516 \\
\hline $\mathrm{I} 13$ & .782 & .037 & 20.851 & .611 \\
\hline $\mathrm{I} 14$ & .898 & .023 & 39.316 & .807 \\
\hline $\mathrm{I} 15$ & .946 & .026 & 36.633 & .895 \\
\hline I16 & .524 & .049 & 10.682 & .275 \\
\hline \multicolumn{5}{|c|}{ ECC (Factor 3) } \\
\hline I17 & .693 & .045 & 15.232 & .480 \\
\hline I18 & .789 & .037 & 21.076 & .622 \\
\hline I19 & .636 & .036 & 17.588 & .405 \\
\hline $\mathrm{I} 20$ & .578 & .038 & 15.081 & .334 \\
\hline $\mathrm{I} 21$ & .760 & .029 & 26.498 & .577 \\
\hline $\mathrm{I} 22$ & .773 & .032 & 24.328 & .597 \\
\hline $\mathrm{I} 23$ & .798 & .028 & 28.338 & .637 \\
\hline \multicolumn{5}{|c|}{ ESI (Factor 4) } \\
\hline $\mathrm{I} 24$ & .808 & .023 & 35.243 & .653 \\
\hline $\mathrm{I} 25$ & .819 & .064 & 12.827 & .671 \\
\hline I 26 & .856 & .017 & 49.221 & .732 \\
\hline I 27 & .908 & .017 & 53.869 & .825 \\
\hline I 28 & .845 & .021 & 39.956 & .714 \\
\hline
\end{tabular}


Table 1 continued

\begin{tabular}{|c|c|c|c|c|}
\hline & $\lambda$ & S.E. & $\mathbf{Z}$ & $\mathbf{R}^{2}$ \\
\hline \multicolumn{5}{|c|}{ ECN (Factor 5) } \\
\hline I29 & .764 & .043 & 17.829 & .584 \\
\hline $\mathrm{I} 30$ & .792 & .033 & 23.854 & .627 \\
\hline I31 & .854 & .030 & 28.387 & .730 \\
\hline $\mathrm{I} 32$ & .818 & .043 & 18.997 & .669 \\
\hline I33 & .867 & .034 & 25.171 & .752 \\
\hline \multicolumn{5}{|c|}{ FSOL (Factor 6) } \\
\hline I34 & .785 & .030 & 26.339 & .616 \\
\hline $\mathrm{I} 35$ & .773 & .029 & 26.961 & .598 \\
\hline I36 & .696 & .034 & 20.233 & .484 \\
\hline I37 & .510 & .048 & 10.670 & .260 \\
\hline $\mathrm{I} 38$ & .967 & .013 & 72.752 & .936 \\
\hline I39 & .940 & .015 & 64.782 & .884 \\
\hline \multicolumn{5}{|c|}{ PCDS (Factor 7) } \\
\hline $\mathrm{I} 40$ & .846 & .022 & 38.895 & .715 \\
\hline I41 & .887 & .016 & 54.929 & .787 \\
\hline $\mathrm{I} 42$ & .916 & .014 & 63.437 & .838 \\
\hline $\mathrm{I} 43$ & .835 & .022 & 37.598 & .698 \\
\hline
\end{tabular}

Note: PT: Proficiency with technology, EOI: Expectations for the online instructor, ECC: Expectations about course content, ESI: Expectations about social interaction, ECN: Expectations about course navigation, FSOL: Facilitators associated with successful online learning, PCDS: Proficiency with the course delivery system. All critical values are at least significant at $\mathrm{p}<.001$ level.

Table 1 shows the item factor loading values, standard errors of the item factor load values, critical values and $\mathrm{R}^{2}$ values obtained as a result of confirmatory factor analysis. $\mathrm{R}^{2}$ values are the amount of variance in the item described by the model tested (Kelloway, 2015).

As can be seen in Table 1, the standardized item factor loading values in proficiency with technology subdimension ranged between .78 and .94 , in expectations for the online instructor sub-dimension ranged between .67 and .95 , in expectations about course content sub-dimension ranged between .58 and .80 , in expectations about social interaction sub-dimension ranged between .81 and .91 , in expectations about course navigation sub-dimension ranged between .76 and .87 , in facilitators associated with successful online learning subdimension ranged between .51 and .97 , in proficiency with the course delivery system sub-dimension ranged between .84 and .92 . All $\mathrm{z}$ values for the 7 -factor model are at least significant at $\mathrm{p}<.001$. It is also seen that $\mathrm{R}^{2}$ values vary between .26 and .94 . When these findings are evaluated as a whole, it indicates that the scale shows a good fit for the seven-factor structure. The factor loadings of the Turkish equivalent form of the SEOLS-R scale are presented in Figure 1. 


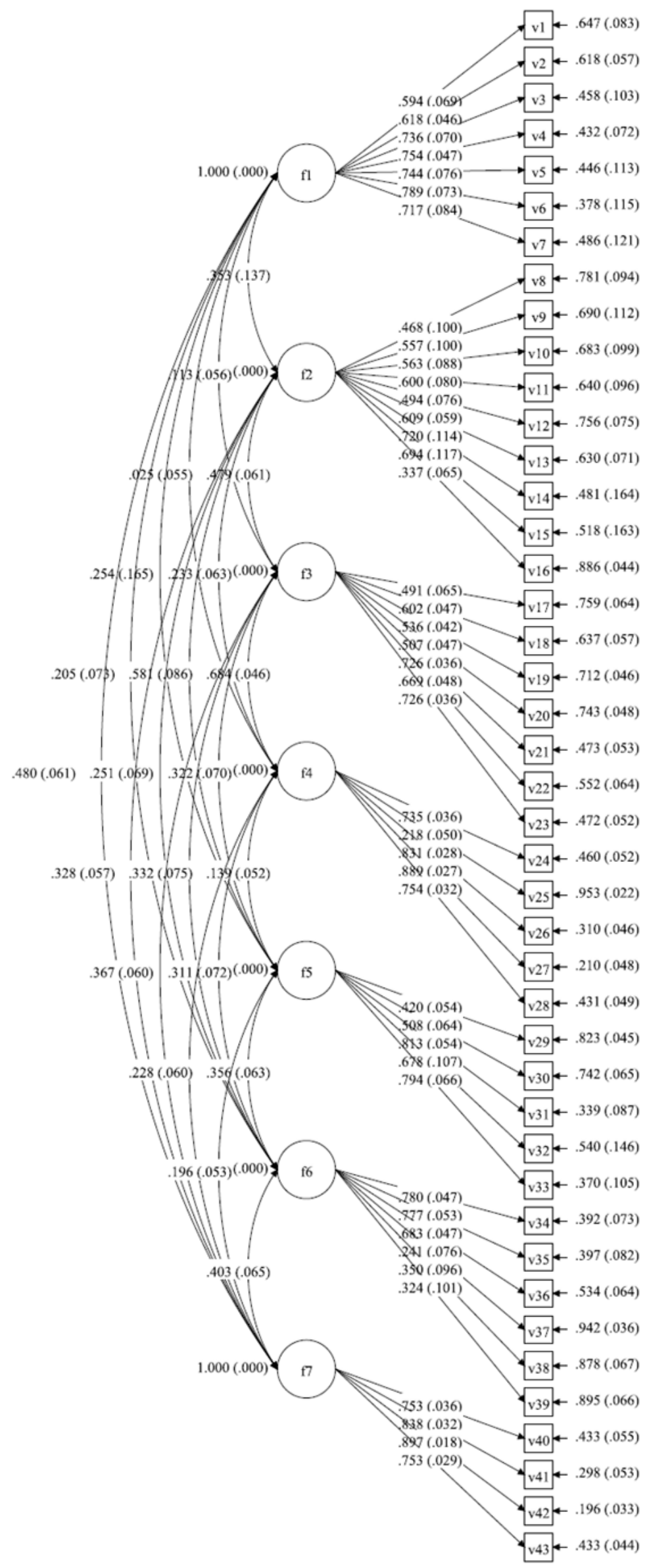

Figure 1. Factor loadings of the Turkish equivalent form of the SEOLS-R scale 


\subsection{Reliability Findings}

Following the construct validation of the SEOLS-R, its reliability was examined with item total correlations, Cronbach Alpha internal consistency coefficients and composite reliability coefficients. Table 2 shows the item total correlations and Cronbach Alpha internal consistency coefficients of each sub-dimension.

Table 2. SEOLS-R item total correlations and Cronbach Alpha internal consistency coefficients

\begin{tabular}{|c|c|c|c|}
\hline & $\mathbf{r}$ & & $\mathbf{r}$ \\
\hline PT (Factor 1) & & $\overline{\text { EOI (Factor 2) }}$ & \\
\hline I1 & .59 & I8 & .40 \\
\hline I2 & .60 & I9 & .51 \\
\hline I3 & .71 & I10 & .51 \\
\hline I4 & .69 & I11 & .54 \\
\hline I5 & .65 & I12 & .49 \\
\hline I6 & .70 & I13 & .56 \\
\hline I7 & .61 & I14 & .55 \\
\hline \multirow[t]{3}{*}{ Cronbach Alpha $(\alpha)$} & .86 & I15 & .51 \\
\hline & & I16 & .33 \\
\hline & & Cronbach Alpha $(\alpha)$ & .77 \\
\hline ECC (Factor 3) & & ESI (Factor 4) & \\
\hline $\mathrm{I} 17$ & .40 & I24 & .68 \\
\hline I18 & .53 & I25 & .20 \\
\hline I19 & .48 & I26 & .74 \\
\hline $\mathrm{I} 20$ & .47 & I27 & .80 \\
\hline I 21 & .63 & I 28 & .70 \\
\hline I22 & .55 & Cronbach Alpha $(\alpha)$ & .83 \\
\hline I23 & .64 & & \\
\hline Cronbach Alpha $(\alpha)$ & .79 & & \\
\hline ECN (Factor 5) & & FSOL (Factor 6) & \\
\hline I 29 & .42 & I34 & .46 \\
\hline I30 & .49 & I35 & .44 \\
\hline $\mathrm{I} 31$ & .63 & I36 & .46 \\
\hline $\mathrm{I} 32$ & .50 & I37 & .34 \\
\hline I33 & .63 & I38 & .61 \\
\hline \multirow[t]{2}{*}{ Cronbach Alpha $(\alpha)$} & .74 & I39 & .56 \\
\hline & & Cronbach Alpha $(\alpha)$ & .74 \\
\hline \multicolumn{4}{|l|}{ PCDS (Factor 7) } \\
\hline $\mathrm{I} 40$ & .69 & & \\
\hline I41 & .78 & & \\
\hline I42 & .83 & & \\
\hline I43 & .69 & & \\
\hline Cronbach Alpha $(\alpha)$ & .88 & & \\
\hline
\end{tabular}

Note: PT: Proficiency with technology, EOI: Expectations for the online instructor, ECC: Expectations about course content, ESI: Expectations about social interaction, ECN: Expectations about course navigation, FSOL: Facilitators associated with successful online learning, PCDS: Proficiency with the course delivery system. $r=$ item total correlations.

As can be seen in Table 2, item total correlations of proficiency with technology sub-dimension ranged between .59 and .71 , expectations for the online instructor sub-dimension ranged between .33 and .66, expectations about course content sub-dimension ranged between .40 and .64 , expectations about social interaction sub-dimension ranged between .20 and .80 , expectations about course navigation sub-dimension ranged between .42 and .63 , facilitators associated with successful online learning sub-dimension ranged between .34 and .61 , proficiency with the course delivery system sub-dimension ranged between .69 and .83 . Researchers suggest that item total correlations should be at least .20 and above (Büyüköztürk, 2010; Nunnally $\&$ Bernstein, 1994). The positive and high item total correlations mean that the item shows similar behaviors and the internal consistency of the test is high (Alış, 2017). In this context, when item total correlations of SEOLS-R sub-dimensions are examined, it can be said that all items have sufficient item total correlation. Cronbanch Alpha internal consistency coefficients of the SEOLS-R sub-dimensions are as below; proficiency with technology is .86, expectations for the online instructor is .77, expectations about course content is .79, expectations about social interaction is .83, expectations about course navigation is .74, facilitators associated with successful online learning is .74 , proficiency with the course delivery system is .88 . As a rule, researchers state that instruments with Cronbach Alpha internal consistency coefficient of .70 and above can be used for 
research purposes (DeVellis, 2012; Nunnally \& Bernstein, 1994). In this context, it can be said that all subdimensions of the scale can be used for research purposes.

Total scores and correlation values between the factors of the SEOLS-R scale are presented in Table 3.

Table 3. Total scores and correlation values between the factors of the SEOLS-R scale $(\mathrm{N}=411)$

\begin{tabular}{lcccccccc}
\hline Factors & PT & EOI & ECC & ESI & ECN & FSOL & PCDS & $\begin{array}{c}\text { Total } \\
\text { Scores }\end{array}$ \\
\hline PT & $.870^{* *}$ & & & & & & $.467^{*}$ \\
EOI & $.262^{*}$ & $.769^{* *}$ & & & & & $.641^{*}$ \\
ECC & .077 & $.432^{*}$ & $.722^{* *}$ & & & & $.741^{*}$ \\
ESI & .044 & $.304^{*}$ & $.620^{*}$ & $.848^{* *}$ & & & $.680^{*}$ \\
ECN & $.192^{*}$ & $.483^{*}$ & $.316^{*}$ & $.321^{*}$ & $.820^{* *}$ & & $.568^{*}$ \\
FSOL & $.143^{*}$ & $.206^{*}$ & $.351^{*}$ & $.359^{*}$ & $.286^{*}$ & $.793^{* *}$ & $.610^{*}$ & $.872^{* *}$ \\
PCDS & $.457^{*}$ & $.297^{*}$ & $.330^{*}$ & $.211^{*}$ & $.232^{*}$ & $.652^{*}$ \\
\hline
\end{tabular}

Note: PT: Proficiency with technology, EOI: Expectations for the online instructor, ECC: Expectations about course content, ESI: Expectations about social interaction, ECN: Expectations about course navigation, FSOL: Facilitators associated with successful online learning, PCDS: Proficiency with the course delivery system.

${ }^{*} \mathrm{p}<.01$ ( 2 tailed) ${ }^{* *}$ Square root of the average variance explained

According to the Table 3, relation between proficiency with technology (PT) and expectations about course navigation $(\mathrm{ECN})$ shows a medium-level relation with total scores, while there is a high-level relation between other factors and total scores. When the correlations between the structures were analyzed, it can be found that all correlations are positive, only the relations between expectations about course content (ECC) and expectations about social interaction (ESI) factors with proficiency with technology are not statistically significant, and all other relationships are significant at the level of $\mathrm{p}<.01$. The diagonal values of the correlation matrix shown in Table 3 represent the square root of the average variance explained. Fornell and Larcker (1981) stated that the discriminant validity can be achieved by the square root of the average variance explained for each structure is larger than the correlations between that structure and other structures. When Table 3 is examined according to this point of view, it can be said that discriminant validity is provided because the square root of the variance explained in relation to all structures is larger than the correlations between that structure and other structures.

Average variance explained and composite reliability coefficients of SEOLS-R scale factors are presented in Table 4.

Table 4. Average variance explained and composite reliability coefficients of SEOLS-R scale factors

\begin{tabular}{lcc}
\hline Factors & Average Variance Explained & Composite Reliability Coefficients \\
\hline PT & .757 & .956 \\
EOI & .591 & .927 \\
ECC & .522 & .883 \\
ESI & .719 & .927 \\
ECN & .672 & .911 \\
FSOL & .629 & .908 \\
PCDS & .760 & .927 \\
\hline
\end{tabular}

Note: PT: Proficiency with technology, EOI: Expectations for the online instructor, ECC: Expectations about course content, ESI: Expectations about social interaction, ECN: Expectations about course navigation, FSOL: Facilitators associated with successful online learning, PCDS: Proficiency with the course delivery system.

According to the Table 4, the average variance explained vary between .522 and .760 . For the convergent validity, based on the values of average variance explained and factor loadings for each item are greater than .50 criteria as Fornell and Larcker (1981) suggested; the factor loadings shown in Table 2 and the values of average variance explained seen in Table 4 are greater than .50, so the convergent validity is provided. As seen in Table 4 , the composite reliability coefficients vary between .883 and .956 . Since these values exceed the critical value determined as .60 by Bagozzi and Yi (1988), it can be said that construct reliability is provided. Ensuring construct validity and reliability means that the adapted SEOLS-R scale is valid and reliable. The final form of the SEOLS-R scale, which was finalized after validity and reliability studies, is presented in Appendix 1.

\section{Results and Recommendations}

In this study, the SEOLS-R scale developed by Harris et al. (2011) is adapted to Turkish culture. It has been tested whether the proposed seven-factor structure of the scale is also valid for Turkish culture, and as a result of the findings, it was decided that there is a cultural compatibility and SEOLS-R can be used as a data collection instrument in Turkish studies. All dimensions of the scale are shown in Figure 2. 


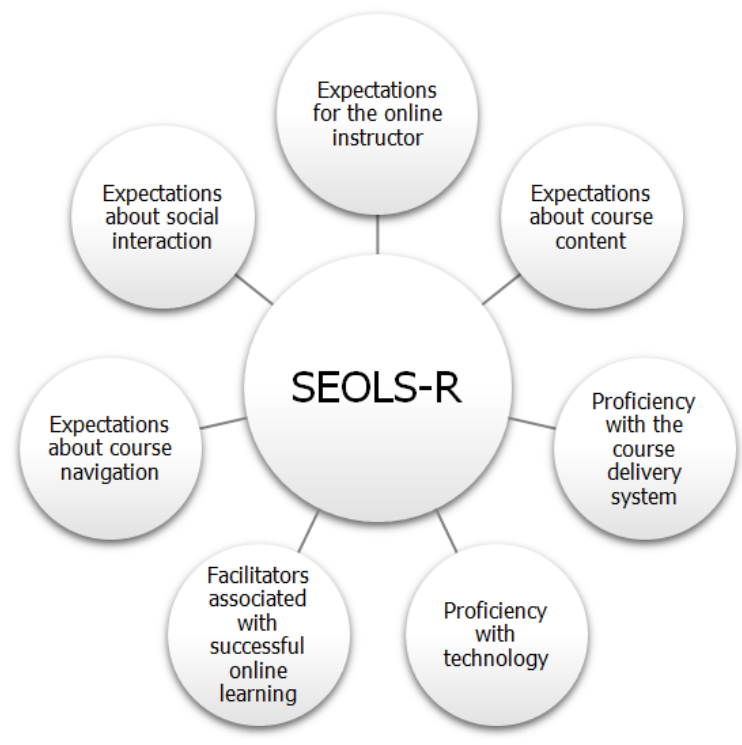

Figure 2. Schematic representation of SEOLS-R's factor structures

When the goodness of fit indices of the SEOLS-R scale are examined, $\chi^{2}(839)$ value is $1865.877, \chi^{2} / \mathrm{df}$ ratio is 2.224 , CFI value is .938 , TLI value is .934 , RMSEA value is $.055,90 \%$ confidence interval lower limit value of RMSEA is .051 and $90 \%$ confidence interval upper limit value of RMSEA is .058. When these goodness of fit indices are analyzed according to the values reported in the studies of Bentler (1990), Schermelleh-Engel, Moosbrugger and Müller (2003), Bentler and Bonett (1980), and Hu and Bentler (1999), they are acceptable and corresponds to a good fit. When the Cronbach Alpha internal consistency coefficients for each dimension of the scale and the Cronbach Alpha internal consistency coefficient (.897) for the entire scale are examined, it can be said that the reliability of the scale is also provided. Cronbach Alpha internal consistency coefficients of the original scale are also known to vary between .64 and .95 on the basis of dimensions.

It may be suggested to test this instrument in different studies occasionally and to test its validity and reliability again. In addition, although this measurement tool is adapted to Turkish culture with cross-sectional data collected at a certain time, it is useful to measure student expectations regarding online learning environments in order to determine its relationship with other variables.

In order for the contribution of this scale adaptation process to be more meaningful and useful, the individual expectations to be measured with SEOLS-R in future studies should be associated with academic performance, persistency of learning, course completion or dropout rates. With the results obtained from SEOLS-R, directors of online distance education programs, course designers, and instructors of online courses can develop strategies for the development of online courses towards students' expectations.

This scale adaptation study has been done on adult students. One of the limitations of this research is the difference between students which take online courses, and which did not take is not examined, so validity and reliability studies on a mixed group is not carried on. In future studies, it may be suggested to use this scale and re-examine its psychometric properties in two different groups in order to measure the differences in expectations among professional and novice online learners. It may be possible to adjust the group dynamics by determining the differences between the expectations of students with professional online learning experience and those of novice students.

No detailed research has been found in the national literature on dropout statistics and comparison of these statistics with reasons of dropout. With this scale, more descriptive data can be obtained by making quantitative reviews. 


\section{Appendix 1. Student Expectations of Online Learning Survey Revised (SEOLS-R) Scale (Turkish Version)}

\section{Likert Rating of the Scale}

1: Strongly Disagree, 2: Disagree, 3: Neutral, 4: Agree, 5: Strongly Agree

\section{Dimensions and Items}

\section{Proficiency with Technology}

1.I am proficient in using a computer on my own.

2.I am proficient in using a word processing software program like Microsoft Word on my own.

3.I am proficient in using email on my own.

4.I am proficient in attaching files to email messages on my own.

5.I am proficient in using the internet on my own.

6.I am proficient in doing internet searches for personal reasons on my own.

7.I am proficient in doing internet searches for school work on my own.

\section{Expectations for the Online Instructor}

8.I expect the course instructor to be clear in communicating the goals of the course. 9.I expect the course instructor to be clear in communicating expectations of me.

10. I expect the course instructor to post course requirements within an agreed upon time.

11. I expect the course instructor to provide constructive feedback on assignments

12. I expect the course instructor to have a consistent presence in the discussion forums.

13. I expect the course instructor to promote a supportive online learning environment.

14. I expect the course instructor to have an appropriate online tone.

15. I expect the course instructor to be responsive to students' tone in the course room.

16. I expect the course instructor to provide instructor contact information to students.

\section{Expectations about Course Content}

17. I expect this online course to be as rigorous as face to face courses.

18. I expect this online course to provide me with opportunities for active learning.

19. I expect this online course to provide me with opportunities for large group discussion.

20. I expect this online course to provide me with opportunities for small group discussion.

21. I expect this online course to provide me with opportunities for self- reflection.

22. I expect this online course to provide me with opportunities to relate theory to real life.

23. I expect this online course to require thoughtful discussion postings rom students.

\section{Expectations about Social Interaction}

24. I expect this online course to provide me opportunities to meet new people.

25. I expect peer comments to be made in a respectful manner.

26. I expect that online interactions with my classmates will be as frequent as face to face interactions.

27. I expect to have as many opportunities to get to know my classmates online as I would face to face.

28. I expect to feel positive about online interaction with my peers.

\section{Expectations about Course Navigation}

29. I expect the course delivery system to be easy to navigate.

30. I expect the course forum names to be clearly stated.

31 . I expect the course topic titles to be clearly stated.

32. I expect the course materials to be easy to locate.

33. I expect the course instructions to be clearly stated.

\section{Facilitators associated with successful online learning}

34. I feel that effective time management will enable me to succeed in this course.

35. I feel that being an independent learner will enable me to succeed in this course.

36. I feel that this online course provides me with flexibility to succeed in this course.

37. I feel that having the support of my family will enable me to succeed in this course.

38. I feel that having the support of my friends will enable me to succeed in this course.

39. I feel that having a positive home environment will enable me to succeed in this course.

\section{Proficiency with the course delivery system}

40. I am proficient in using the "Message" feature in the courseroom. 41. I am proficient in using the "Dropbox" feature in the courseroom.

42. I am proficient in using the "Discussion Forum" feature in the courseroom.

43. I am proficient in using the "Resource" feature in the courseroom. 


\section{Revize Edilmiş Çevrimiçi Öğrenmeye İlişsin Öğrenci Beklentileri Ölçeğinin (SEOLS-R) Türkçeye Uyarlanması}

\section{Giriş}

Yetişkin öğrencilerin yaşamlarında var olan, ailevi sorumluluklar, zaman kısıtlllığı ve mesai bağlayıcıllğ gibi çok sayıda etken, örgün eğitimden ziyade çevrimiçi uzaktan eğitim programlarının tercih edilmesine neden olmaktadır. Bu noktada çevrimiçi uzaktan eğitim programları, bu tür öğrencilerin eğitim almalarına olanak sağlamaya dönük oldukça elverişli imkânlar sunabilmektedir. Bu programlara kayıt olup öğrenime başlayan ve programın gerekliliklerini yerine getirip başarıyla mezun olan öğrenciler, daha iyi bir gelecek, daha iyi bir çalışma pozisyonu, daha çok mesleki bilgi veya daha yüksek akademik derece elde edebilmektedirler. Ne var ki, bu programlar için, sorumluluklarının yanı sıra zaman, para ve çaba sarf eden öğrenciler için başarı her zaman mümkün olamamaktadır. Programların, karşılanmayan beklentiler, sorumluluklar ya da programın gerekliliklerini yerine getirememe gibi nedenlerle terk edilmesi, hem öğrencinin bireysel gelecek planlaması açısından hem de bu programları sunan Uzaktan Eğitim Uygulama ve Araştırma Merkezleri (UZEM) gibi akademik birimler açısından ciddi kayıplara dönüşebilmektedir. Okur, Paşaoğlu-Baş ve Uça-Güneş'e (2019) göre akademik veya mesleki kariyer beklentisi olmayan öğrencilerin karşılaştıkları olumsuz olaylar karşısında daha kolay vazgeçmeleri, okul bırakma veya kayıt yaptırmama sebeplerinden biridir. Harris, Larrier ve CastanoBishop (2011) yükseköğretim kurumlarındaki çevrimiçi öğrenme ortamlarında öğrenci kaybı sorununun uzaktan eğitim yöneticilerinin dikkatini çektiğini vurgulamaktadır. Bu kayıpların önüne geçebilmek için öğrencilerin çevrimiçi öğrenme ortamlarına ilişkin beklentilerinin incelenmesi, terk eylemini daha iyi anlamaya ve çözümler üretebilmeye olanak sağlayabilir. Okur ve arkadaşlarına (2019) göre, öğrenimi bırakma nedenlerinin belirlenmesi, bırakma, ara verme ya da terk etme sorunlarının çözümü noktasında önemli veriler sağlayabilir. Bu sayede, öğrencilerin programlardan beklentilerinin gerçekçi düzeyde olup olmadığı, çevrimiçi ortamlarda eğiticilerin kullandıkları yöntem, teknik veya materyallerin, öğrencilerin ve programların gerekliliklerini ne düzeyde karşıladığı öğrenilebilir. Öğrencilerin kayıttan, eğitimi terk etmelerine kadar olan zaman içinde kendi aralarındaki etkileşimleri, eğitmenleriyle olan iletişimleri ve eğitim süresince ihtiyaç duydukları desteklerin incelenmesi ve iyi belirlenmesi, öğrencilerin eğitimi terk etmelerini önlemeye yardımcı olabilir.

Uygun çevrimiçi öğrenme ortamlarının tasarlanması, geliştirilmesi ve içeriklerin teminine odaklanılan süreçte, eğitimine başladığ halde devam etmeyip bırakan öğrencilerin sayısındaki artıs, eğitimcilerin temel kaygılardandır (O'Brien, 2002; Parker, 1999). Genellikle uzaktan eğitimi terk oranları, yüz yüze eğitimi terk oranlarından daha yüksektir. Birçok öğrenci çevrimiçi dersleri terk etmekte veya memnuniyetsiz bir şekilde bitirmeye çalışmaktadır (Keegan, 1990; Morgan ve Tam, 1999; Willging ve Johnson, 2009). Rovai'ye (2003) göre eğitim sürecinin tamamlama oranı, eğitimin kalitesi hakkında bir ölçüt olarak kullanılabilir. Kampüs içi eğitimi terk oranı \%15 ile \%25 arasında iken, çevrim içi derslerde \%40'lara kadar çıkabilmektedir (Parker, 1999, 2003; Xenos, 2004). Açıköğretim ve çevrimiçi uzaktan eğitim programlarının tamamlama oranlarının düşük olması öğrenen özellikleri, motivasyon, memnuniyet gibi öğrenciye bağlı nedenlerden (Willging ve Johnson, 2009) kaynaklanabilirken, öğrencilerin iş ve aile sorumlulukları da (Xenos, Pierrakeas ve Pintelas, 2002) eğitime devam etmelerine engel olabilmektedir.

Türkiye'de öğrencilerin uzaktan eğitim programlarını terk etme oranlarını ele alan sınırlı sayıda araştırma vardır. Bu araştırmalarda genel olarak terk nedenlerinin ele alındığı, ama terk etme veya bırakma oranlarına değinilmediği görülmektedir. Okur ve arkadaşlarının (2019) derleme nitelikli çalışmalarında okuldan ve programdan kaynaklanan faktörler, öğrencinin kişisel özelliklerinden kaynaklı faktörler ve sosyal çevreden kaynaklı faktörlere değinilmiştir. Arslan (2018) ise eğitim terkini, içsel faktörler, dışsal faktörler, tercih nedeni, kişisel özellikler ve beklentiler başlıklarıyla sınıflamıştır. Fakat Türkiye'de eğitim terkine ilişkin sayısal veriler bilinmemektedir. Öncelikle oranlar ve istatistikler üzerine kapsayıcı nicel verilere gereksinim vardır. Daha sonra eğitimi sürdürme / bırakma oranları ve nedenlerinin karşılaştırmalı olarak incelenmesine ihtiyaç duyulmaktadır.

Alanyazında çevrimiçi uzaktan eğitim programlarının terk edilmesinde önemli rolü olan faktörlerden birinin öğrencilerin beklentilerinin karşılanamaması olduğu vurgulanmaktadır (Bezerra ve Silva, 2017; Laskaris, 2015; Onah, Sinclair ve Boyatt, 2014). Ulusal alanyazında da terke neden olan faktörlerden birisinin beklentiler olduğu Arslan (2018) tarafindan dile getirilmektedir. Tam bu noktada Harris ve arkadaşlarının (2011), geliştirdikleri SEOLS-R ölçeğinin kuramsal çerçevesinin Beklenti Kuramına temellendiğini ifade etmektedirler. Bu kuram, gelecekteki eylemlerin beklenen sonuçlarının ne ölçüde karşılandığının nasıl doğrulanacağını açıklayan bir çerçeve sağlamaktadır (Isaac, Zerbe ve Pitt, 2001). Çevrimiçi eğitimi sürdürme, derslerden vazgeçmeme bağlamında Beklenti Kuramı, öğrencilerin çevrimiçi derslerdeki beklentilerinin ne ölçüde karşılandığının öğrencilerin çevrimiçi dersleri almaya devam edip etmeyeceklerini etkileyeceğine karşlık gelmektedir. Öğrenci beklentileri ders deneyimleriyle tutarlı olduğunda, öğrencilerin çevrimiçi öğrenme ortamında kalmaları daha olasıdır. Öğrenci beklentileri hakkında bilgi ve anlayışa sahip olmak ve bu beklentilerin öğrenci performansını 
ve kalıc1lığını nasıl etkilediği, öğrencilerin çevrimiçi kurslar için gerçekçi beklentiler geliştirmelerine yardımcı olacak programlar geliştirmenin ilk adımıdır.

$\mathrm{Bu}$ araştırmada SEOLS-R ölçeğinin kuramsal temelinin dayandığı Beklenti Kuramı, Vroom’un (1964) çalı̧̧masına temellenmektedir. Daha sonra Porter ve Lowler (1968) tarafindan çaba-performans ilişkisi üzerine bir model geliştirilmiştir. Bu model genellikle Beklenti Kuramı olarak adlandııılmakla birlikte, VIE kuramı olarak da bilinmektedir ve V değer (valence), I araçsallık (instrumentality) ve E beklenti (expectancy) şeklinde bir sıralamayla açıklanmaktadır (Isaac ve ark., 2001). Vroom'a (1964) göre valance, bir bireyin çeşitli sonuçlar arasında seçim yapmasına yardımcı eden zihinsel canlandırma odaklı bir değerdir (Anık, 2007). Araçsallık ise, ara amaçların olduğu durumlar için daha uygun düşen, bir ödüle ulaşabilmek için başka ara amaçlara odaklanan bir kavramdır. Anık’a (2007) göre araçsallık, kişinin tatmin olacağına inandığı bir sonuca belirli birtakım araçlar sayesinde ulaşabileceği inancını biçimlendirerek, onun davranışını şekillendirilebileceğini göstermektedir. Beklenti Kuramının son temel bileşeni olan beklenti kavramı ise, bir bireyin bir amaca ulaşabilmek için kendisinde geliştirdiği içsel öngörü, inanç veya kanaattir. Beklenti Kuramı aslında, bir motivasyon ve davranış kuramıdır. Bu araştırmada ele alınan SEOLS-R ölçeği ile Beklenti Kuramının ilişkisi, çevrimiçi eğitime ilişkin beklentilerinin karşılanması durumunda, öğrencilerin çevrimiçi programlarda devam etme ve mezun olma olasılıklarının daha yüksek olduğu varsayımından gelmektedir (Harris ve ark., 2011). Dolayısıyla SEOLS-R ölçeği, öğrencilerin çevrimiçi derslere devam etmeleri üzerinde etkisi olabilecek yapıları nicel olarak ölçebilecek yapıda güvenilir bir ölçme aracıdır (Harris ve ark., 2011).

Pek çok çalışmanın çevrimiçi uzaktan eğitim programlarını terk etme nedenlerini ele aldığını ama çok az sayıda çalışmada öğrenci beklentileri ile terk etme arasındaki ilişkinin incelendiğini vurgulayan Harris ve arkadaşları (2011), alanyazındaki bu boşluğu dolduracak sistematik bir yönteme ihtiyaç olduğuna dikkati çekmişlerdir. Tam bu noktada, çevrimiçi uzaktan eğitim programlarını terk eden öğrencilerin çevrimiçi ders öğelerine ilişskin beklentilerini belirleyebilmek amacıyla Harris ve arkadaşları (2011) tarafindan SEOLS-R ölçeği geliştirilmiştir. Alanyazında bu amaçla geliş̧irilmiş başka bir ölçeğe rastlanmamıştır. Çevrimiçi öğrenmeye ilişkin öğrenen hazır bulunuşluğu, topluluk hissi, öğrenci bağlllı̆̆ı, motivasyonu, tutumu gibi konularda alanyazında pek çok ölçek geliştirilmiş veya uyarlanmış olsa da Harris ve arkadaşlarının (2011) işaret ettiği, çevrimiçi uzaktan eğitim programlarını terk etme nedenlerini açıklayabilecek bir öğrenci beklentileri ölçeğinin olmayışı önemli bir eksikliktir. Buradan hareketle bu araştırmanın amacı, SEOLS-R ölçeğini Türkçeye uyarlamaktır. SEOLS-R'nin geçerlik ve güvenirlik çalışması daha önce Türk kültüründe gerçekleştirilmediğinden bu çalışma bağlamında ilk olarak ölçeğin kültürel adaptasyon çalışmaları yapılmış, daha sonra geçerlik ve güvenirliği incelenmiştir. Türk kültürüne böyle bir ölçeğin kazandırılması, ulusal düzeyde giderek yaygınlaşan çevrimiçi uzaktan eğitimlerde öğrenci beklentilerinin ölçülebilmesi ve bu beklentiler belirlendikten sonra eğitim terki noktasında bazı tedbirler alınabilmesine firsat sunabilecek potansiyele sahip olunması bakımından önemli görülmektedir.

\section{Yöntem}

$\mathrm{Bu}$ araştırma kültürlerarası bir ölçek uyarlama çalışması niteliği taşımaktadır. Bu amaçla özgün şekli İngilizce dilinde geliştirilen ölçeğin Türkçe'ye uyarlanması amaçlanmıştır. Bu uyarlama sürecinde Deniz (2007) tarafından sıralanan ölçek uyarlama adımlarından bu çalışma için uygun olanları, sıralama değiştirilmeden izlenmiştir. Söz konusu aşamalar bu başlık altında açıklanmaktadır.

\subsection{Katılımellar}

SEOLS-R ölçeğinin uyarlama sürecinde veri toplanan grup, Amasya Üniversitesinin uzaktan eğitim programlarına devam etmekte olan 411 öğrenciden oluşmaktadır. Bu öğrenciler Pedagojik Formasyon Eğitimi Sertifika Programına kayıtlı öğrencilerdir ve teorik dersleri tamamen çevrimiçi öğrenme ile almaktadırlar. Öğrenciler SEOLS-R ölçeğini ve demografik bilgilerden oluşan kısa anketi çevrimiçi ortamda cevaplamışlardır. Öğrencilere verdikleri cevapların gizli kalacağı, verilerin araştırma amacı dışında kullanılmayacağ bilgi verilmiş ve tüm öğrencilerin araştırmaya gönüllü olarak katılmaları sağlanmıştır. Araştırmaya katılan öğrencilerin 148'i (\%36) erkek ve 263'ü (\%64) kadındır. Katılımcıların yaş dağılımı 21 ile 42 arasında değişmekte olup, yaş ortalamaları ise $26.06^{\prime}$ dır (standart sapma: 4.11). Medeni durum açısından ise katılımcıların \%76'sı (n=313) bekâr ve \%24'ü (n=98) evlidir. Katılımcıların \%14'ü (n=59) daha önce çevrimiçi bir eğitim programına katılmışken, \%86’sı (n=352) herhangi bir çevrimiçi eğitim programına katılmamışır.

\section{2. Özgün Ölçeğe İlişkin Bilgiler}

SEOLS-R ölçeğinin kuramsal temelleri Beklenti Kuramı'na dayanmaktadır. Beklentilerin, insan davranışlarının temel ilkelerinden olduğunu ve bireysel beklentilerin çeşitli durumlarda karşılanma derecesinin, bir kişinin sonraki davranış tercihlerini de etkileyeceğini vurgulayan Harris ve arkadaşları (2011), bu anlayıştan hareketle, bir öğrencinin çevrimiçi derste beklentilerinin ne derece karşılandığının, öğrencinin çevrimiçi dersi almaya devam edip etmeyeceğini etkileyeceğini ifade etmektedirler. Araştırmacılar bu varsayımdan hareketle, öğrencilerin çevrimiçi öğrenme beklentilerini ölçebilecek bir ölçme aracına ihtiyaç olduğuna karar vermişlerdir. 
İlk sürümü 44 madde halinde hazırlanan ölçme aracının geçerlik ve güvenirlik çalışmaları yapılmıştır. Geçerlik için görünüş geçerliği ve kapsam geçerliği incelenmiş, güvenirlik için ise madde-toplam korelasyonları ve Cronbach alfa iç tutarlılık katsayıları hesaplanmıştır. Görünüş geçerliği için öğrenciler ve uzmanlardan oluşan iki panel, ölçeği incelemiş ve görüşlerini belirtmişlerdir. Kapsam geçerliği için de, uzmanlardan oluşan panelin görüşleri temel alınmıştır. Güvenirlik için, her bir boyutun Cronbach alfa iç tutarlılık katsayılarının .64 ile .95 arasında değiştiği görülmüştür. Madde toplam korelasyonları 0,25 veya daha yüksek olan maddeler ankette tutulmuştur. Bu ilk pilot çalışma sonrasında eklenen ve silinen maddeler olmuş, ölçek revize edilerek 5'li Likert yapıda 7 faktör ve 43 maddeden oluşan son şekline ulaşmıştır.

Harris ve arkadaşları (2011) tarafından geliştirilen SEOLS-R ölçeği, öğrencilerin çevrimiçi öğrenme beklentilerini teknoloji yeterliliği, çevrimiçi ders öğreticisinden beklentiler, ders içeriğinden beklentiler, sosyal etkileşim beklentileri, ders gezinimi beklentileri, başarılı bir çevrimiçi öğrenmeyi kolaylaştırıcılar, ders iletim sistemine dair yeterlilikler boyutlarında ölçmeyi amaçlamaktır. Teknoloji yeterliliği alt boyutu kişinin bilgisayar kullanımına ilişkin temel becerilere ne düzeyde sahip olduğunu belirlemeyi amaçlamaktadır. Bu alt boyuttan örnek bir madde "Kendi başıma kişisel bilgisayar kullanabilirim." şeklindedir. Çevrimiçi ders öğreticisinden beklentiler alt boyutu, katılımcıların çevrimiçi ders öğretmeninden ders öğretimi sürecinde beklentilerini belirlemeyi amaçlamaktadır. Bu alt boyuttan örnek bir madde "Öğretim elemanının, dersin hedeflerini açıkça belirtmesini beklerim.” şeklindedir. Ders içeriğinden beklentiler, öğrencilerin çevrimiçi dersin nasıl işlenmesi gerektiğine dair beklentilerini ölçmeyi amaçlamaktadır. Bu alt boyuttan örnek bir madde "Çevrimiçi dersin bana aktif öğrenme olanakları sunmasını beklerim." şeklindedir. Sosyal etkileşim beklentileri, katılımcıların çevrimiçi öğrenme ortamında nasıl sosyal ilişkiler olması gerektiğine ilişkin beklentilerini içermektedir. Bu alt boyuttan örnek bir madde "Sınıf arkadaşlarımla çevrimiçi etkileşimlerimin, yüz yüze arkadaşlarım kadar sık olmasını beklerim." şeklindedir. Ders gezinimi beklentileri, katılımcıların dersin yönerge ve materyallerine kolayca ulaşabilme, ders konu başlıklarının ve ders forumlarının açık ve anlaşılabilir olmasına ilişkin beklentilerini ölçmeyi amaçlamaktadır. Bu alt boyuttan bir örnek madde "Ders materyallerini kolayca bulabilmeyi beklerim." şeklindedir. Başarılı bir çevrimiçi öğrenmeyi kolaylaştırıcılar alt boyutu ise çevrimiçi öğrenme sürecinde katılımcıların başarılı olmalarını kolaylaştıran aile, arkadaş ortamı, çevrimiçi derse ilişkin olumlu faktörler ve kişisel faktörlerin rolünün ne düzeyde olduğunu belirlemeyi amaçlamaktadır. $\mathrm{Bu}$ alt boyuttan örnek bir madde “Arkadaş desteğine sahip olmamın, bu eğitimde başarılı olmamı sağladığııı düşünüyorum.” şeklindedir. Son olarak, ders iletim sistemine dair yeterlilikler, katılımcıların çevrimiçi öğrenme ortamlarının mesaj atma, ödev yükleme, tartışma forumlarını kullanma gibi özelliklerini kullanabilmekte ne düzeyde yeterli olduklarına ilişkin algılarını ölçmeyi amaçlamaktadır. Bu boyuttan örnek bir madde "Çevrimiçi ortamda, "ödev yükleme" özelliğini kullanmada yeterliyim.” şeklindedir. SEOLS-R yukarıda belirtildiği gibi 7 alt boyuttan oluşan bir ölçme aracıdır. Katılımcılar her bir alt boyutta yer alan ölçek ifadelerine katılma derecelerini Kesinlikle Katılmıyorum'dan (1), Kesinlikle Katılıyorum'a (5) uzanan seçeneklerden birini işaretleyerek belirtmektedir. Her bir alt boyuttan alınan puanların artması, ilgili alt boyuta ilişkin katılımcıların değerlendirmelerinin olumlu ya da beklentilerinin yüksek olduğu anlamına gelmektedir. Ölçekten en az 43, en çok 215 puan alınabilmektedir.

\section{3. Ölçeğin Türkçe Formunun Hazırlanması}

SEOLS-R'nin uyarlanması amacıyla ilk olarak ölçek sahipleriyle e-mail yoluyla iletişime geçilerek ölçeğin uyarlanabilmesi için gereken izin alınmıştır. İkinci aşamada, ölçeğin çeviri işlemi gerçekleştirilmiştir. Ölçeğin çeviri işlemlerinin gerçekleştirilmesinde Brislin (1970) tarafından önerilen işlem adımları takip edilmiştir. İlk olarak, özgün ölçek araştırmacılar tarafından Türkçe diline çevrilmiş, daha sonra Bilgisayar ve Öğretim Teknolojileri Eğitimi bölümünde görev yapmakta olan Türkçe ve İngilizce dillerine hâkim, ölçek geliştirme ve uyarlama çalışmaları hakkında bilgi sahibi olan başka bir araştırmacı tarafından geri çeviri işlemi gerçekleştirilmiştir. Bu araştırmacının uzaktan eğitimde çevrimiçi ders verme deneyimi olup, aynı zamanda da Uzaktan Eğitim Uygulama ve Araştırma Merkezinde yöneticilik görevi bulunmaktadır. Üçüncü aşamada, geri çeviri işlemi yapılan taslak ölçek ile özgün ölçek karşılaştırılmış ve uzlaşma sağlanamayan sınırlı sayıda maddenin yeniden tercümesi yapılmıştır. Daha sonra araştırma konusuna aşina olmayan ancak İngilizce diline hâkim başka bir araştırmacı tarafından geri çeviri işlemi gerçekleştirilmiş ve özgün ölçekteki maddelerle karşılaştırılması sağlanmıştır. Bu süreç sonunda geri çeviri işlemi gerçekleştirilen maddelerle ve özgün ölçekteki maddelerinin aynı olduğu görülmüştür. Gelinen bu noktada terimler veya kavramlar açısından diller arasında anlamsal veya kavramsal eşdeğerlik eksikliği olmadığı görülmüştür. SEOLS-R'nin, Türkçe diline uyarlanmasını takiben ölçeğin geçerliği ve güvenirliği incelenmiştir.

\subsection{Verilerin Analizi}

SEOLS-R'nin yap1 geçerliğini incelemek amacıyla doğrulayıcı faktör analizi gerçekleştirilmiştir. Alanyazında iki tür faktör analizi, ölçeklerin yapı geçerliklerinin test edilmesinde sıklıkla kullanılmaktadır (Brown, 2015; Harrington, 2009). Bunlar sırasıyla açımlayıcı faktör analizi ve doğrulayıcı faktör analizidir. Açımlayıcı faktör analizi araştırmacıların faktör yapısı hakkında önceden çok az bilgi sahibi oldukları ya da hiç bilgi sahibi olmadıkları ölçeklerin faktör yapısını belirlemek, başka bir ifadeyle teorik bir yapı geliştirmek amacıyla kullandıkları çok değişkenli istatistiksel bir yöntem iken, doğrulayıcı faktör analizi ise var olan bir 
teorik yapının farklı bir örneklemde ya da kültürde benzer olup olmadığını test etmek amacıyla kullanılan çok değişkenli istatistiksel bir yöntemdir (Brown, 2015). Açımlayıcı faktör analizinde ölçeğin faktör yapısı bilinmezken, doğrulayıcı faktör analizinde bilinen bir faktör yapısının farklı bir kültürde ya da örneklemde test edilerek benzer olup olmadığı belirlenmeye çalışılmaktadır. Bu çalışmada benzer şekilde, SEOLS-R'nin, Harris ve arkadaşları (2011) tarafından belirlenen faktör yapısının Türk kültüründe benzer olup olmadığını belirleyebilmek amacıyla doğrulayıcı faktör analizi kullanılmıştır.

Bu çalışmada doğrulayıcı faktör analizinin yürütülmesinde Mplus (Muthén ve Muthén, 2011) programından yararlanılmıştır. Katılımcıların SEOLS-R maddelerine verdikleri cevaplar ortalamaya ve varyansa göre düzeltilmiş ağırlıklandırılmış en küçük kareler tahmin yöntemi (Weighted Least Squares Means and Variance Adjusted - WLSMV) kullanılarak analiz edilmiştir. Araştırmacılar, doğrulayıcı faktör analizinde sıklıkla kullanılan maksimum olabilirlik tahmin yönteminin, normal dağılım göstermeyen ya da sınırlı sayıda cevaplama kategorisine sahip, sıralama tipi ölçek maddeleriyle kullanıldığında doğru olmayan sonuçlar verebileceğini belirtmektedir (Finney ve DiStefano, 2006). Alanyazında WLSMV tahmin yönteminin sınırlı sayıda cevaplama kategorisine sahip Likert tipi ölçeklerde, daha doğru faktör yük değerleri tahminleri, daha doğru uyum iyiliği indeksleri sunduğu, normal dağılım göstermeyen ve küçük örneklem büyüklüklerinde daha iyi performans sergilediği belirtilmektedir (Beauducel ve Herzberg, 2006). Bu bağlamda, SEOLS-R maddelerinin sınırlı sayıda cevaplama kategorisine sahip, Likert tipi ölçek maddelerinden oluştuğu dikkate alınarak bu çalışmada WLSMV tahmin yöntemi kullanılmıştır. Doğrulayıcı faktör analizinde test edilen modelin model veri uyumu uyum iyiliği indeksleri aracılığıyla incelenmektedir. Mplus programı, WLSMV tahmin yöntemi kullanıldığında rapor edilmesi önerilen dört farklı uyum iyiliği indeksi oluşturmaktadır (McDonald ve Ho, 2002). Bunlar sırasıyla Kikarenin serbestlik derecesine oranı $\left(\chi^{2} / \mathrm{sd}\right)$, Yaklaşık Hataların Ortalama Karekökü (RMSEA), Karşılaştırmalı Uyum İndeksi (CFI), Normlaştırılmamış Uyum İndeksi (Non Normed Fit Index [NNFI] veya Tucker-Lewis Index [TLI]) uyum iyiliği indeksleridir. TLI, alanyazında NNFI olarak da bilinmektedir (Cangur ve Ercan, 2015). Little (2013), Mplus yazılımında TLI indeksinin, LISREL yazılımında ise NNFI'nın raporlandığını, ikisinin de farklı zamanlarda farklı araştırma grupları tarafından geliştirilmekle birlikte, araştırmalarda kullanımı sirasında tercihin yazarlara ait olduğunu ifade etmektedir.

Alanyazında model veri uyumunu değerlendirmek için genel bir kural olarak, $\chi^{2} /$ sd değerinin 2 'den büyük ve 5 'ten küçük ya da eşit olması $\left(2<\chi^{2} / \mathrm{sd} \leq 5\right)$, RMSEA değerinin .05 ile .08 aralığında olması $(0.05 \leq \mathrm{RMSEA} \leq 0.08)$ kabul edilebilir uyuma işaret etmektedir. Diğer taraftan CFI ve TLI değerleri için kabul edilebilir uyum değerleri, .90 ve üzeri olmasıdır (Hu ve Bentler, 1999; Kline, 2011; Marsh, Balla ve McDonald, 1988; McDonald ve Marsh, 1990). Yukarıda belirtilen indeksler için mükemmel uyum değerleri ise $\chi^{2} /$ sd oranı için 2'nin altı, CFI ve TLI için .95 ve üstü, RMSEA için .05 ve altı olarak belirtilmektedir (Hu ve Bentler, 1999; Kline, 2011; Marsh, ve ark., 1988; McDonald ve Marsh, 1990).

Araştırma verilerinin doğrulayıcı faktör analizi ile incelenmeye başlanmasından önce toplanan veriler incelenmiştir. Veri ayıklamaya gerek olup olmadığ göz önüne alınmıştır. Veriler çevrimiçi ortamda toplandığ 1 için tüm soruların yanıtlanması sağlanmıştır. Bu nedenle kayıp veri bulunmamaktadır. Veri setinde uç değer de yer almadığı için, herhangi bir veri ayıklama yapılmamıştır. Toplanan veri seti analize olduğu gibi dâhil edilmiştir.

Faktör analiz öncesinde verinin analize uygunluğunu sinayabilmek için Kaiser-Meyer-Olkin (KMO) örneklem uygunluğu testi ile Bartlett'in Küresellik testi gerçekleştirilmiştir. KMO değerinin .856 ve $\chi^{2}=8877.664 ; \mathrm{p}<.05$ olduğu görülmüştür. Bu istatistikler, verinin faktörleşebileceğine ve örneklem genişliğinin uygunluğuna işaret etmektedirler.

SEOLS-R'nin güvenirliği ise madde toplam korelasyonları, Cronbach Alfa iç tutarlılık katsayıları ve birleşik güvenirlik katsayıları aracılığıyla incelenmiştir.

\section{Bulgular}

Bu kısımda önce SEOLS-R ölçeğinin Türkçe formuna ait yapı geçerliği bulguları, daha sonra güvenirlik bulguları sunulmuştur.

\subsection{Geçerlik Bulguları}

SEOLS-R'nin Harris ve arkadaşları (2011) tarafından önerilen yedi faktörlü yapısının Türk kültürü için de geçerli olup olmadığının anlaşılabilmesi için doğrulayıcı faktör analizi gerçekleştirilmiştir. Doğrulayıcı faktör analizi gerçekleştirilmeden önce, modelin tanımlanabilmesi amacıyla her bir maddenin faktör varyansları 1'e sabitlenmiş ve faktörlerin birbiriyle ilişkili olmasına izin verilmiştir. Bunun sebebi, ölçekteki her bir yapının mutlaka ölçeklenmesine firsat sunmak ve ölçek belirsizliğini önlemektir. Brown’a (2015) göre faktör varyanslarını 1'e sabitlemek, modeli tanımlamaktadır ve parametre tahminleri girdi matrisini mükemmel bir şekilde yeniden üretmeyi sağlamaktadır. Gerçekleştirilen doğrulayıcı faktör analizi sonucunda, test edilen modelin veri uyumunun kabul edilebilir düzeyde olduğu görülmüştür [ $\chi^{2}(839): 1865.877, \chi^{2}$ /sd: 2.224 , CFI: .938, 
TLI: .934, RMSEA: .055, RMSEA \%90 Güven Aralığ1 Alt Sınır: .051, RMSEA \%90 Güven Aralığ1 Üst Sınır: .058]. Bu uyum değerleri, herhangi bir modifikasyona gerek kalmadan tek seferde elde edilen uyum değerleridir.

Tablo 1. Doğrulayıcı faktör analizi sonuçları

\begin{tabular}{|c|c|c|c|c|}
\hline & $\lambda$ & S.H. & $\mathbf{Z}$ & $\mathbf{R}^{2}$ \\
\hline \multicolumn{5}{|c|}{ TY (Faktör 1) } \\
\hline M1 & .779 & .036 & 21.940 & .607 \\
\hline M2 & .768 & .033 & 23.258 & .591 \\
\hline M3 & .908 & .026 & 34.378 & .825 \\
\hline M4 & .894 & .020 & 44.473 & .800 \\
\hline M5 & .883 & .030 & 29.826 & .780 \\
\hline M6 & .943 & .018 & 52.576 & .890 \\
\hline M7 & .898 & .026 & 33.961 & .806 \\
\hline \multicolumn{5}{|c|}{ ÇDÖB (Faktör 2) } \\
\hline M8 & .673 & .047 & 14.312 & .453 \\
\hline M9 & .783 & .044 & 17.784 & .613 \\
\hline M10 & .740 & .040 & 18.362 & .548 \\
\hline M11 & .774 & .045 & 17.272 & .599 \\
\hline M12 & .718 & .041 & 17.400 & .516 \\
\hline M13 & .782 & .037 & 20.851 & .611 \\
\hline M14 & .898 & .023 & 39.316 & .807 \\
\hline M15 & .946 & .026 & 36.633 & .895 \\
\hline M16 & .524 & .049 & 10.682 & .275 \\
\hline \multicolumn{5}{|c|}{ DİB (Faktör 3) } \\
\hline M17 & .693 & .045 & 15.232 & .480 \\
\hline M18 & .789 & .037 & 21.076 & .622 \\
\hline M19 & .636 & .036 & 17.588 & .405 \\
\hline M20 & .578 & .038 & 15.081 & .334 \\
\hline M21 & .760 & .029 & 26.498 & .577 \\
\hline M22 & .773 & .032 & 24.328 & .597 \\
\hline M23 & .798 & .028 & 28.338 & .637 \\
\hline \multicolumn{5}{|c|}{ SEB (Faktör 4) } \\
\hline M24 & .808 & .023 & 35.243 & .653 \\
\hline M25 & .819 & .064 & 12.827 & .671 \\
\hline M26 & .856 & .017 & 49.221 & .732 \\
\hline M27 & .908 & .017 & 53.869 & .825 \\
\hline M28 & .845 & .021 & 39.956 & .714 \\
\hline \multicolumn{5}{|c|}{ DGB (Faktör 5) } \\
\hline M29 & .764 & .043 & 17.829 & .584 \\
\hline M30 & .792 & .033 & 23.854 & .627 \\
\hline M31 & .854 & .030 & 28.387 & .730 \\
\hline M32 & .818 & .043 & 18.997 & .669 \\
\hline M33 & .867 & .034 & 25.171 & .752 \\
\hline \multicolumn{5}{|c|}{ BBÇÖK (Faktör 6) } \\
\hline M34 & .785 & .030 & 26.339 & .616 \\
\hline M35 & .773 & .029 & 26.961 & .598 \\
\hline M36 & .696 & .034 & 20.233 & .484 \\
\hline M37 & .510 & .048 & 10.670 & .260 \\
\hline M38 & .967 & .013 & 72.752 & .936 \\
\hline M39 & .940 & .015 & 64.782 & .884 \\
\hline \multicolumn{5}{|c|}{ DİSDY (Faktör 7) } \\
\hline M40 & .846 & .022 & 38.895 & .715 \\
\hline M41 & .887 & .016 & 54.929 & .787 \\
\hline M42 & .916 & .014 & 63.437 & .838 \\
\hline M43 & .835 & .022 & 37.598 & .698 \\
\hline
\end{tabular}

Not: TY: Teknoloji yeterliliği, ÇDÖB: Çevrimiçi ders öğreticisinden beklentiler, DỉB: Ders içeriğinden beklentiler, SEB: Sosyal etkileşim beklentileri, DGB: Ders gezinimi beklentileri, BBÇÖK: Başarılı bir çevrimiçi öğrenmeyi kolaylaştırıcılar, DİSDY: Ders iletim sistemine dair yeterlilikler. Tüm kritik değerler en az $\mathrm{p}<.001$ düzeyinde anlamlıdır. 
Tablo 1'de doğrulayıcı faktör analizi sonucu elde edilen madde faktör yük değerleri, madde faktör yük değerlerinin standart hataları, kritik değerler ve $\mathrm{R}^{2}$ değerleri görülmektedir. $\mathrm{R}^{2}$ değerleri test edilen model tarafından açıklanan maddedeki varyans miktarıdır (Kelloway, 2015).

Tablo 1'de görüldüğü gibi, teknoloji yeterliliği alt boyutunda standardize edilmiş madde faktör yük değerleri .78 ile .94 arasında değişirken, çevrimiçi ders öğreticisinden beklentiler alt boyutunda .67 ile .95 , ders içeriğinden beklentiler alt boyutunda .58 ile .80 , sosyal etkileşim beklenti alt boyutunda .81 ile .91 , ders gezinimi beklentileri alt boyutunda .76 ile .87 , başarılı bir çevrimiçi öğrenmeyi kolaylaştırıcılar alt boyutunda .51 ile .97 , ders iletim sistemine dair yeterlilikler alt boyutunda .84 ile .92 arasında değişmektedir. Test edilen 7 faktörlü modele ilişkin tüm $\mathrm{z}$ değerleri en az $\mathrm{p}<.001$ düzeyinde anlamlıdır. Aynı zamanda $\mathrm{R}^{2}$ değerlerinin de .26 ile .94 arasında değiştiği görülmektedir. Bu bulgular bir bütün olarak değerlendirildiğinde, ölçeğin yedi faktörlü yap1 için iyi bir uyum sergilediğine işaret etmektedir. SEOLS-R ölçeğinin Türkçe eşdeğer formunun faktör yükleri bütüncül olarak Şekil 1'de sunulmuştur.

\subsection{Güvenirlik Bulguları}

SEOLS-R'nin yapı geçerliğinin doğrulanmasının ardından, güvenirliği ise madde toplam korelasyonları, Cronbach Alfa iç tutarlılık katsayıları ve birleşik güvenirlik katsayılarıyla incelenmiştir. Tablo 2'de her bir alt boyutun madde toplam korelasyonları ve Cronbach Alfa iç tutarlılık katsayıları görülmektedir.

Tablo 2. SEOLS-R madde toplam korelasyonları ve Cronbach Alfa iç tutarlılık katsayıları

\begin{tabular}{|c|c|c|c|}
\hline & $\mathbf{r}$ & & $\mathbf{r}$ \\
\hline TY (Faktör 1) & \multicolumn{3}{|c|}{ ÇDÖB (Faktör 2) } \\
\hline M1 & .59 & M8 & .40 \\
\hline M2 & .60 & M9 & .51 \\
\hline M3 & .71 & M10 & .51 \\
\hline M4 & .69 & M11 & .54 \\
\hline M5 & .65 & M12 & .49 \\
\hline M6 & .70 & M13 & .56 \\
\hline M7 & 61 & M14 & .55 \\
\hline \multirow[t]{3}{*}{ Cronbach Alfa $(\alpha)$} & .86 & M15 & .51 \\
\hline & & M16 & .33 \\
\hline & & Cronbach Alfa $(\alpha)$ & .77 \\
\hline DİB (Faktör 3) & \multicolumn{3}{|c|}{ SEB (Faktör 4) } \\
\hline M17 & .40 & M24 & .68 \\
\hline M18 & .53 & M25 & .20 \\
\hline M19 & .48 & M26 & .74 \\
\hline M20 & .47 & M27 & .80 \\
\hline M21 & .63 & M28 & .70 \\
\hline M22 & .55 & Cronbach Alfa $(\alpha)$ & .83 \\
\hline M23 & .64 & & \\
\hline Cronbach Alfa $(\alpha)$ & .79 & & \\
\hline DGB (Faktör 5) & \multicolumn{3}{|c|}{ BBÇÖK (Faktör 6) } \\
\hline M29 & .42 & M34 & .46 \\
\hline M30 & .49 & M35 & .44 \\
\hline M31 & .63 & M36 & .46 \\
\hline M32 & .50 & M37 & .34 \\
\hline M33 & .63 & M38 & .61 \\
\hline Cronbach Alfa $(\alpha)$ & .74 & M39 & .56 \\
\hline & & Cronbach Alfa $(\alpha)$ & .74 \\
\hline \multicolumn{4}{|l|}{ DİSDY (Faktör 7) } \\
\hline M40 & 69 & & \\
\hline M41 & .78 & & \\
\hline M42 & .83 & & \\
\hline M43 & .69 & & \\
\hline Cronbach Alfa $(\alpha)$ & .88 & & \\
\hline
\end{tabular}




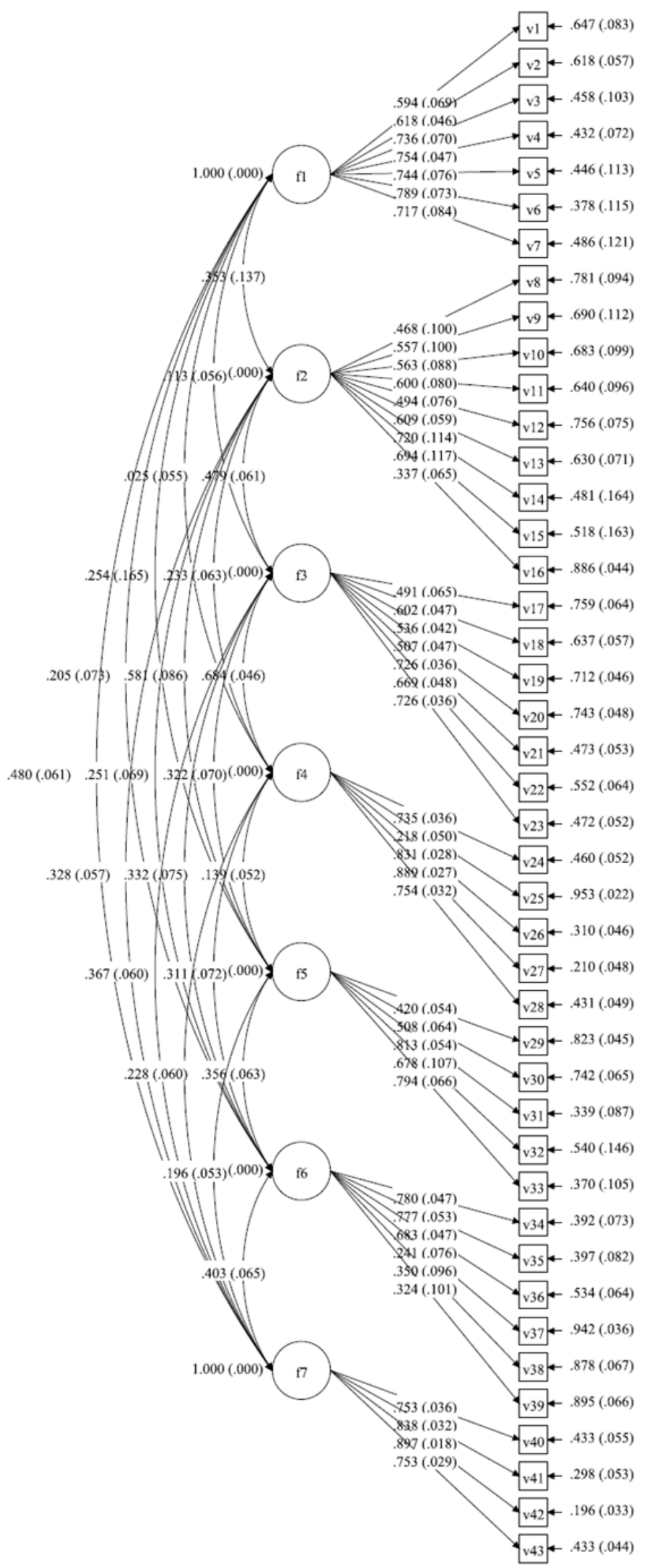

Şekil 1. SEOLS-R ölçeğinin Türkçe eşdeğer formunun faktör yükleri 
Tablo 2'de görüldüğü gibi teknoloji yeterliliği alt boyutu madde toplam korelasyonlar1 .59 ile .71 arasında, çevrimiçi ders öğreticisinden beklentiler alt boyutu .33 ile .66, ders içeriğinden beklentiler alt boyutu .40 ile .64 arasında, sosyal etkileşim beklentileri alt boyutu .20 ile .80, ders gezinimi beklentileri alt boyutu .42 ile .63 arasında, başarılı bir çevrimiçi öğrenmeyi kolaylaştırıcılar alt boyutu .34 ile .61, ders iletim sistemine dair yeterlilikler alt boyutu .69 ile .83 arasında değişmektedir. Araştırmacılar madde toplam korelasyonlarının en düşük .20 ve üzerinde olmasını önermektedir (Büyüköztürk, 2010; Nunnally ve Bernstein, 1994). Madde toplam korelasyonlarının pozitif ve yüksek olması, maddenin benzer davranışları örneklediği ve testin iç tutarlılığının yüksek olduğu anlamına gelmektedir (Alış, 2017). Bu bağlamda, SEOLS-R alt boyutlarının madde toplam korelasyonları incelendiğinde tüm maddelerinin yeterli düzeyde madde toplam korelasyonuna sahip olduğu söylenebilir. SEOLS-R alt boyutlarının iç tutarlılık katsayıları incelediğinde teknoloji yeterliliği alt boyutunun .86, çevrimiçi ders öğreticisinden beklentiler alt boyutunun .77, ders içeriğinden beklentiler alt boyutunun .79, sosyal etkileşim beklentileri alt boyutunun .83, ders gezinimi beklentileri alt boyutunun .74, başarılı bir çevrimiçi öğrenmeyi kolaylaştırıcılar alt boyutunun .74, ders iletim sistemine dair yeterlilikler alt boyutunun .88 Cronbanch Alfa iç tutarlılık katsayısına sahip olduğu görülmüştür. Genel bir kural olarak araştırmacılar .70 ve üzerinde Cronbach Alfa iç tutarlılık katsayısına sahip ölçme araçlarının araştırma amacıyla kullanılabileceğini belirtilmektedir (DeVellis, 2012; Nunnally ve Bernstein, 1994). Bu bağlamda, ölçeğin tüm alt boyutlarının araştırma amacıyla kullanılabileceği söylenebilir.

SEOLS-R ölçeğinin toplam puan ve faktörler arasındaki korelasyon değerleri Tablo 3 'de sunulmuştur.

Tablo 3. SEOLS-R ölçeğinin toplam puan ve faktörler arasındaki korelasyon değerleri $(\mathrm{N}=411)$

\begin{tabular}{|c|c|c|c|c|c|c|c|c|}
\hline $\begin{array}{l}\text { Faktör } \\
\text { isimleri }\end{array}$ & TY & ÇDÖB & DİB & SEB & DGB & BBÇÖK & DİSDY & $\begin{array}{c}\text { Toplam } \\
\text { Puan }\end{array}$ \\
\hline $\mathrm{TY}$ & $.870^{* * *}$ & & & & & & & $.467^{*}$ \\
\hline ÇDÖB & $.262^{*}$ & $.769^{* *}$ & & & & & & $.641^{*}$ \\
\hline DİB & .077 & $.432^{*}$ & $.722^{* * *}$ & & & & & $.741^{*}$ \\
\hline SEB & .044 & $.304^{*}$ & $.620^{*}$ & $.848^{\text {*** }}$ & & & & $.680^{*}$ \\
\hline DGB & $.192^{*}$ & $.483^{*}$ & $.316^{*}$ & $.321^{*}$ & $.820^{* *}$ & & & $.568^{*}$ \\
\hline BBÇÖK & $.143^{*}$ & $.206^{*}$ & $.351^{*}$ & $.359^{*}$ & $.286^{*}$ & $.793^{* *}$ & & $.637^{*}$ \\
\hline DİSDY & $.457^{*}$ & $.297^{*}$ & $.330^{*}$ & $.211^{*}$ & $.232^{*}$ & $.310^{*}$ & $.872^{* * *}$ & $.652^{*}$ \\
\hline
\end{tabular}

Tablo 3 incelendiğinde teknoloji yeterliliği (TY) ve ders gezinimi beklentileri (DGB) faktörlerinin toplam puanlar ile orta düzeyde ilişki gösterdiği, diğer faktörler ile toplam puanlar arasında ise yüksek düzeyde bir ilişki olduğu görülmektedir. Yapılar arasındaki korelasyonlar incelendiğinde ise tüm korelasyonların pozitif yönlü olduğu, sadece ders içeriğinden beklentiler (DİB) ve sosyal etkileşim beklentileri (SEB) faktörleri ile teknoloji yeterliliği arasındaki ilişkilerin istatistiksel olarak anlamlı olmadığı, diğer tüm ilişkilerin ise $p<.01$ düzeyinde anlamlı olduğu bulgusuna ulaşılmıştır. Tablo 3'de görülen korelasyon matrisinin diyagonal değerleri ise ortalama açıklanan varyansın karekökünü ifade etmektedir. Fornell ve Larcker (1981) ayırt edici geçerliğin, her bir yapıya ilişkin ortalama açıklanan varyansın karekökünün, o yapı ve diğer yapılar arasındaki korelasyonlardan daha büyük olmasıyla sağlanabileceğini ifade etmektedir. Buradan hareketle Tablo 3 incelendiğinde, tüm yapılara ilişkin olarak ortalama açıklanan varyansın karekökünün, o yap1 ve diğer yapılar arasındaki korelasyonlardan daha büyük olması nedeniyle ayırt edici geçerliğin sağlandığı söylenebilir.

SEOLS-R ölçeğinin faktörlerine ilişkin ortalama açıklanan varyans (average variance explained) ve birleşik güvenirlik katsayıları (composite reliability coefficient) Tablo 4'de sunulmuştur.

Tablo 4. SEOLS-R ölçeğinin faktörlerine ilişkin ortalama açıklanan varyans ve birleşik güvenirlik katsayıları

\begin{tabular}{lcc}
\hline Faktör isimleri & Ortalama Açklanan Varyans & Birleşik Güvenirlik Katsayları \\
\hline TY & .757 & .956 \\
ÇDÖB & .591 & .927 \\
DİB & .522 & .883 \\
SEB & .719 & .927 \\
DGB & .672 & .911 \\
BBÇÖK & .629 & .908 \\
DİSDY & .760 & .927 \\
\hline
\end{tabular}

Not: TY: Teknoloji yeterliliği, ÇDÖB: Çevrimiçi ders öğreticisinden beklentiler, DỉB: Ders içeriğinden beklentiler, SEB: Sosyal etkileşim beklentileri, DGB: Ders gezinimi beklentileri, BBÇÖK: Başarılı bir çevrimiçi öğrenmeyi kolaylaștırıcılar, DİSDY: Ders iletim sistemine dair yeterlilikler 
Tablo 4 incelendiğinde, ortalama açıklanan varyans değerlerinin .522 ile .760 aralığında değiştiği görülmektedir. Yakınsama geçerliği için Fornell ve Larcker'in (1981) önerdiği, ortalama açıklanan varyans değerlerinin ve her bir maddeye ilişkin faktör yüklerinin .50'den büyük olması kriterleri temel alındığında, Tablo 2'de görülen faktör yükleri ve Tablo 4'de görülen ortalama açıklanan varyans değerlerinin tamamının .50'den büyük olduğu ve buradan hareketle de yakınsama geçerliğinin sağlandığı söylenebilir. Yine Tablo 4'de görüldüğü üzere birleşik güvenirlik katsayıları, .883 ile .956 arasında değişmektedir. Bu değerler Bagozzi ve Yi (1988) tarafından .60 olarak belirlenen kritik değeri aştığ1 için yapı güvenirliğinin sağlandığı söylenebilir. Yap1 geçerliği ve güvenirliğinin sağlanması, uyarlanan SEOLS-R ölçeğinin geçerli ve güvenilir olduğu anlamına gelmektedir. Geçerlik ve güvenirlik çalışmaları yapılarak son şekli verilen SEOLS-R ölçeğinin Türkçe formu Ek 1 'de sunulmuştur.

\section{Sonuçlar ve Öneriler}

$\mathrm{Bu}$ araştırmada Harris ve arkadaşları (2011) tarafindan geliştirilen SEOLS-R ölçeğinin Türk kültürüne uyarlaması yapılmıştır. Ölçeğin önerilen yedi faktörlü yapısının Türk kültürü için de geçerli olup olmadığ sınanmış, elde edilen bulgular neticesinde kültürel uyumun olduğuna ve SEOLS-R'nin Türkçe araştırmalarda bir veri toplama aracı olarak kullanılabileceğine karar verilmiştir. Ölçeğin tüm boyutları Şekil 2'de bütüncül olarak ortaya konmuştur.

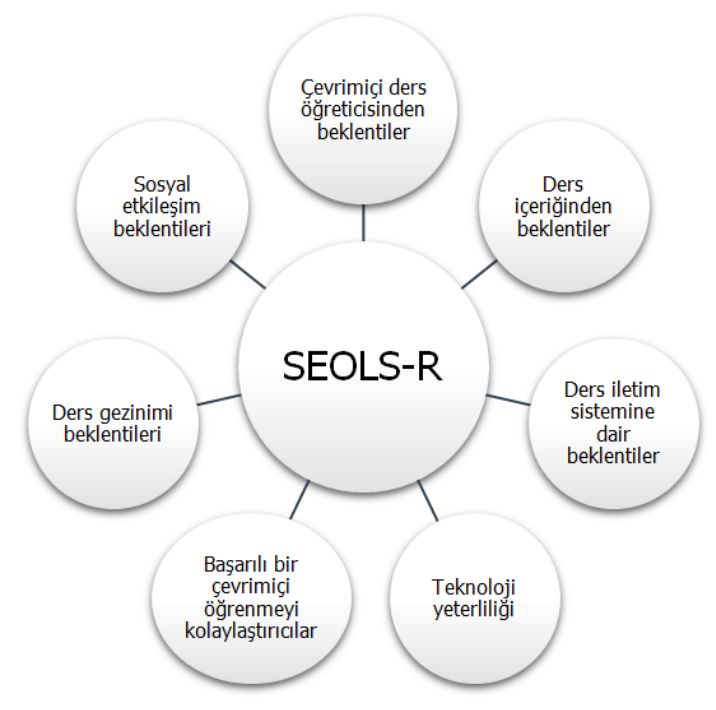

Şekil 2. SEOLS-R'nin faktör yapılarının şematik gösterimi

SEOLS-R ölçeğinin uyum iyiliği indeksleri incelendiğinde, $\chi^{2}(839)$ değerinin $1865.877, \chi^{2} /$ sd oranının 2.224, CFI değerinin .938, TLI değerinin .934, RMSEA değerinin .055, RMSEA \%90 güven aralı̆̆1 alt sınır değerinin .051 ve RMSEA \%90 güven aralığ üst sınır değerinin ise .058 olduğu görülmüştür. Bu uyum iyiliği indeksleri, Bentler (1990), Schermelleh-Engel, Moosbrugger ve Müller (2003), Bentler ve Bonett (1980) ile Hu ve Bentler'in (1999) çalışmalarında rapor edilen değerlere göre incelendiğinde, kabul edilebilir ve iyi bir uyuma karşılık gelmektedir. Ölçeğin her bir boyutuna ilişkin Cronbach Alfa iç tutarlılık katsayıları ve ölçeğin tümüne ilişkin Cronbach Alfa iç tutarlılık katsayısı (.897) incelendiğinde ölçeğin güvenirliğinin da sağlandığ söylenebilir. Özgün ölçeğin Cronbach Alfa iç tutarlılık katsayılarının da boyutlar bazında .64 ile .95 arasında değiştiği bilinmektedir.

$\mathrm{Bu}$ veri toplama aracının zaman zaman farklı çalışmalarda kullanılarak tekrar sınanması ve geçerlik ile güvenirliğinin yeniden test edilmesi önerilebilir. Ayrıca bu ölçme aracı zamanın belli bir anında toplanan kesitsel verilerle Türk kültürüne uyarlanmış olsa da, çevrimiçi öğrenme ortamlarına ilişkin öğrenci beklentilerini ölçerek başka değişkenlerle ilişkisinin belirlenebilmesi amacıyla kullanılmasında fayda vardır.

$\mathrm{Bu}$ ölçeğin uyarlanması sürecinin getirdiği katkının daha anlamlı ve işe vuruk olabilmesi adına bundan sonraki çalışmalarda SEOLS-R ile ölçülecek bireysel beklentilerin, akademik performansla, öğrenmenin kalıcılığıyla, ders tamamlama veya bırakma oranlarıyla ilişkilendirilmesi gerekmektedir. Çevrimiçi uzaktan eğitim programlarının yöneticileri, ders tasarımcıları ve çevrimiçi derslerin öğretmenleri, SEOLS-R'den gelen ölçümlerle çevrimiçi derslerin öğrenci beklentilerine yönelik olarak geliştirilmesine ilişkin stratejiler geliştirebilirler.

Yetişkin öğrenciler üzerinde bir ölçek uyarlama çalışması yapılmış olmakla birlikte, bu araştırmanın bir sınırlılığı, daha önce çevrimiçi bir ders alan ya da almayan öğrenciler arasında bir farka bakılmamış olması, bu anlamda karışık bir grup üzerinde geçerlik ve güvenirlik çalışmalarının yürütülmüş olmasıdır. İlerleyen 
çalışmalarda profesyonel çevrimiçi öğrenenler veya acemiler arasındaki beklenti farklılıklarını da ölçebilmek adına iki ayrı grupta ölçeğin tekrar kullanılması ve hatta psikometrik özelliklerinin yeniden irdelenmesi önerilebilir. Profesyonel anlamda çevrimiçi öğrenme deneyimi olan öğrencilerin beklentileri ile acemi ögrencilerin beklentileri arasındaki farklılıklar belirlenerek grup dinamiklerinin de ayarlanması söz konusu olabilir.

Ulusal alanyazında terk istatistikleri ve bu istatistiklerin terk nedenleriyle kıyaslanması üzerine detaylı bir araştırmaya rastlanmamıştır. Bu ölçek ile nicel taramalar yapılarak daha açıklayıcı verilere ulaşılabilir.

\section{Ek 1. SEOLS-R Ölçeğinin Türkçe Eşdeğer Formu}

\section{Ölçeğin Likert Derecelendirilmesi}

1: Kesinlikle katılmıyorum, 2: Katılmıyorum, 3: Hem katılıyorum, hem katılmıyorum, 4: Katılıyorum, 5: Kesinlikle katılıyorum

\section{Boyutlar ve Maddeler}

1. Kendi başıma bilgisayar kullanabilirim.

2. Kendi başıma kelime işlem programı (Microsoft Word vb.) kullanabilirim.

3. Kendi başıma, e-posta gönderebilirim.

4. Kendi başıma, e-postaya dosya ekleyebilirim.

5. Kendi başıma, internet kullanabilirim.

6. Kendi başıma, kişisel ihtiyaçlarım için internette araştırmalar yapabilirim.

7. Kendi başıma, derslerle (ödev, araştırma vb.) ilgili internet aramaları yapabilirim.

\section{Çevrimiçi Ders Ö̆̆reticisinden Beklentiler}

8. Öğretim elemanının, dersin hedeflerini açıkça belirtmesini beklerim.

9. Öğretim elemanının, benden beklentileri açıkça belirtmesini beklerim.

10. Öğretim elemanının, dersin gereksinimlerini daha önceden belirlenmiş zaman aralıklarını dikkate alarak duyurmasinı beklerim.

11. Öğretim elemanının, ödevlerimi değerlendirirken yapıcı geribildirimler vermesini beklerim.

12. Öğretim elemanının, tartışma forumlarına yeterli derecede katılmasını beklerim.

13. Öğretim elemanının, çevrimiçi öğrenme ortamlarının kullanılması konusunda teşvik etmesini beklerim.

14. Öğretim elemanının, çevrimiçi ortamı kullanırken uygun davranışlar sergilemesini beklerim.

15. Öğretim elemanının, çevrimiçi derslerde öğrencilere yanıtlar verirken uygun davranışlar sergilemesini beklerim.

16. Öğretim elemanının, iletişim bilgilerini öğrencilerle paylaşmasını beklerim.

\section{Ders İçeriğinden Beklentiler}

17. Çevrimiçi derslerin yüz yüze dersler kadar dikkatli bir biçimde işlenmesini beklerim.

18. Çevrimiçi dersin bana aktif öğrenme olanakları sunmasını beklerim.

19. Çevrimiçi dersin bana büyük grup tartışmaları sunmasını beklerim.

20. Çevrimiçi dersin bana küçük grup tartışmaları sunmasını beklerim.

21. Çevrimiçi dersin bana kendimi yansıtma imkânı sunmasını beklerim.

22. Çevrimiçi dersin bana teoriyi gerçek hayatla ilişkilendirme imkânı sunmasını beklerim.

23. Çevrimiçi derslerin, öğrencilerin dersle ilgili anlamlı tartışmalara yönlendirmesini beklerim.

\section{Sosyal Etkileşim Beklentileri}

24. Bu çevrimiçi dersin yeni insanlarla tanışma imkânı sunmasını beklerim.

25. Sınıf arkadaşlarımın yorum yaparken birbirlerine saygılı davranmalarını beklerim.

26. Sınıf arkadaşlarımla çevrimiçi etkileşimlerimin, yüz yüze arkadaşlarım kadar sık olmasını beklerim.

27. Çevrimiçi sınıf arkadaşlarımı tanımak için, yüz yüze etkileşimde olduğu gibi olanaklara sahip olmayı beklerim.

28. Sınıf arkadaşlarımla çevrimiçi etkileşimler hakkında olumlu hissetmeyi beklerim. 


\section{Ders gezinimi beklentileri}

29. Çevrimiçi derslerde gezinmenin kolay olmasını beklerim.

30. Derslerde kullanılan forum isimlerinin açık bir biçimde ifade edilmiş olmasını beklerim.

31. Ders konu başlıklarının açıkça belirtilmiş olmasını beklerim.

32. Ders materyallerini kolayca bulabilmeyi beklerim.

33. Ders yönergelerinin açıkça belirtilmiş olmasını beklerim.

\section{Başarılı bir çevrimiçi öğrenmeyi kolaylaştırıcılar}

34. Etkili zaman yönetiminin, bu eğitimde başarılı olmamı sağladığını düşünüyorum.

35. Bağımsız bir öğrenen olmanın, bu eğitimde başarılı olmamı sağladığını düşünüyorum.

36. Çevrimiçi derslerin, bu eğitimde başarılı olmamda bana esneklik kazandırdığını düşünüyorum.

37. Bu eğitimde başarılı olmamda ailemin desteğinin önemli olduğunu düşünüyorum.

38. Arkadaş desteğine sahip olmamın, bu eğitimde başarılı olmamı sağladığını düşünüyorum.

39. Olumlu bir aile ortamının, bu eğitimde başarılı olmamı sağladığını düşünüyorum.

\section{Ders iletim sistemine dair yeterlilikler}

40. Çevrimiçi ortamda, "mesaj" özelliğini kullanmada yeterliyim.

41. Çevrimiçi ortamda, "ödev yükleme" özelliğini kullanmada yeterliyim.

42. Çevrimiçi ortamda, "tartışma forumları" özelliğini kullanmada yeterliyim.

43. Çevrimiçi ortamda, "kaynaklar" özelliğini kullanmada yeterliyim.

\section{Kaynaklar / References}

Alış, S. (2017, Nisan). Geçiş ölçeğinin Türkçe’ye uyarlanması: Geçerlilik ve güvenirlik çalışması. 3. Uluslararası Multidisipliner Avrasya Kongresi’nde sunulan bildiri, Barselona, İspanya.

Anık, C. (2007). Eğiticinin performansını niteleyen faktörler. Bilig, 43, 133-168.

Arslan, Ö. (2018). Çevrimiçi uzaktan eğitim öğrencilerinin programlarl terk etme nedenlerinin incelenmesi (Yayımlanmamış yüksek lisans tezi). Hacettepe Üniversitesi, Eğitim Bilimleri Enstitüsü, Ankara.

Bagozzi, R. P., \& Yi, Y. (1988). On the evaluation of structural equation models. Journal of the Academy of Marketing Science, 16(1), 74-94.

Beauducel, A., \& Herzberg, P. Y. (2006). On the performance of maximum likelihood versus means and variance adjusted weighted least squares estimation in CFA. Structural Equation Modeling: A Multidisciplinary Journal, 13(2), 186-203.

Bentler, P. M. (1990). Comparative fit indexes in structural models. Psychological Bulletin, 107(2), 238-46.

Bentler, P. M., \& Bonett, D. G. (1980). Significance tests and goodness of fit in the analysis of covariance structures. Psychological Bulletin, 88(3), 588-606.

Bezerra, L., \& Silva, M. (2017). A review of literature on the reasons that cause the high dropout rates in the MOOCS. Revista Espacios, 38(5). Retrieved November 30, 2019 from http://www.revistaespacios.com/a17v38n05/a17v38n05p11.pdf

Brislin, R. W. (1970). Back-translation for cross-cultural research. Journal of Cross-Cultural Psychology, 1(3), $185-216$

Brown, T. A. (2015). Confirmatory factor analysis for applied research. New York: Guilford Press.

Büyüköztürk, Ş. (2010). Sosyal bilimler için veri analizi el kitabı (22. basım). Ankara: Pegem Akademi.

Cangur, S., \& Ercan, I. (2015). Comparison of model fit indices used in structural equation modeling under multivariate normality. Journal of Modern Applied Statistical Methods, 14(1), 152-167.

Deniz, K. Z. (2007). Psikolojik ölçme aracı uyarlama. Ankara Üniversitesi Eğitim Bilimleri Fakültesi Dergisi, 40(1), 1-16.

DeVellis, R. F. (2012). Scale development: Theory and applications (3rd ed.). London: SAGE Publications.

Finney, S. J., \& DiStefano, C. (2006). Nonnormal and categorical data in structural equation. Structural Equation Modeling: A Second Course (In G. R. Hancock \& R. O. Mueller (Eds.), (pp. 269-314). Greenwich, CT: Information Age Publishing.

Fornell, C., \& Larcker, D. F. (1981). Structural equation models with unobservable variables and measurement error. Journal of Marketing Research, 18(1), 39-50.

Harrington, D. (2009). Confirmatory factor analysis. Oxford: Oxford University Press. 
Harris, S. M., Larrier, Y. I., \& Castano-Bishop, M. (2011). Development of the student expectations of online learning survey (SEOLS): A pilot study. Online Journal of Distance Learning Administration, 14(4). $\begin{array}{llll}\text { Retrieved } & \text { November } & 29, & 2019\end{array}$ https://www.westga.edu/ distance/ojdla/winter144/harris_larrier_bishop144.html

Hu, L., \& Bentler, P. M. (1999). Cutoff criteria for fit indexes in covariance structure analysis: Conventional criteria versus new alternatives. Structural Equation Modeling: A Multidisciplinary Journal, 6(1), 1-55.

Isaac, R. G., Zerbe, W. J., \& Pitt, D. C. (2001). Leadership and motivation: The effective application of expectancy theory. Journal of Managerial Issues, 13(2), 212-226.

Keegan, D. (1990). Foundations of distance education (2nd ed.). New York: Routledge Publications.

Kelloway, E. K. (2015). Using Mplus for structural equation modeling: A researcher's guide. Los Angeles: SAGE Publications.

Kline, R. B. (2011). Principles and practice of structural equation modeling (3rd ed.). New York: Guilford Press.

Laskaris, J. (2015). Why do learners drop out of a course? Retrieved November 30, 2019 from https://www.talentlms.com/blog/why-do-learners-drop-out-of-a-course/

Little, T. D. (2013). Longitudinal structural equation modeling. New York: The Guilford Press.

Marsh, H. W., Balla, J. R., \& McDonald, R. P. (1988). Goodness-of-fit indexes in confirmatory factor analysis: The effect of sample size. Psychological Bulletin, 103(3), 391-410.

McDonald, R. P., \& Ho, M. H. R. (2002). Principles and practice in reporting structural equation analyses. Psychological Methods, 7(1), 64-82.

McDonald, R. P., \& Marsh, H. W. (1990). Choosing a multivariate model: Noncentrality and goodness of fit. Psychological Bulletin, 107(2), 247-255.

Morgan, C. K., \& Tam, M. (1999). Unraveling the complexities of distance education student attrition. Distance Education, 20(1), 96-108.

Muthén, L. K., \& Muthén, B. O. (2011). Mplus (Version 6.12) [Computer software]. Los Angeles, CA: Muthén \& Muthén.

Nunnally, J. C., \& Bernstein, I. H. (1994). Psychometric theory. Montréal: McGraw-Hill.

O'Brien, B. (2002). Online student retention: Can it be done? World Conference on Educational Multimedia, Hypermedia and Telecommunications, 2002(1), 1479-1483.

Okur, M. R., Paşaoğlu-Baş, D. ve Uça-Güneş, E. P. (2019). Açık ve uzaktan öğrenmede öğrenimi bırakma sebeplerinin incelenmesi. Yükseköğretim ve Bilim Dergisi, 9(2), 225-235.

Onah, D. F. O., Sinclair, J., \& Boyatt, R. (2014, July). Dropout rates of massive open online courses: Behavioural patterns. Paper presented at the $6^{\text {th }}$ International Conference on Education and New Learning Technologies, Barcelona, Spain.

Parker, A. (1999). A study of variables that predict dropout from distance education. International Journal of Educational Technology, 1(2), 1-12.

Parker, A. (2003). Identifying predictors of academic persistence in distance education. United States Distance Learning Association Journal, 17(1), 55-62.

Porter, L. W., \& Lawler, E. E. (1968). Managerial attitudes and performance. Homewood, IL: Dorsey Press.

Rovai, A. P. (2003). In search of higher persistence rates in distance education online programs. The Internet and Higher Education, 6(1), 1-16.

Schermelleh-Engel, K., Moosbrugger, H., \& Müller, H. (2003). Evaluating the fit of structural equation models: Test of significance and descriptive goodness-of-fit measures. Methods of Psychological Research - Online, $8(2), 23-74$.

Vroom, V. H. (1964). Work and motivation. New York, NY: Wiley.

Willging, P. A., \& Johnson, S. D. (2009). Factors that influence students' decision to dropout of online courses. Journal of Asynchronous Learning Networks, 13(3), 115-127.

Xenos, M. (2004). Prediction and assessment of student behaviour in open and distance education in computers using Bayesian networks. Computers \& Education, 43(4), 345-359.

Xenos, M., Pierrakeas, C., \& Pintelas, P. (2002). A survey on student dropout rates and dropout causes concerning the students in the course of informatics of the Hellenic Open University. Computers \& Education, 39(4), 361-377. 